


\section{'Dutch Solutions for Global Challenges' in het agrofood-domein}

Eric Smaling

Dit onderzoek is uitgevoerd door Wageningen Environmental Research in opdracht van en gefinancierd door het ministerie van Landbouw, Natuur en Voedselkwaliteit, in het kader van het Beleidsondersteunend onderzoekthema 'Voedselzekerheid' (projectnummer 20-007-454).

Wageningen Environmental Research

Wageningen, maart 2018

Rapport 2874

ISSN 1566-7197 
Eric Smaling, 2018. 'Dutch Solutions for Global Challenges' in het agrofood-domein. Wageningen, Wageningen Environmental Research, Rapport 2874. 38 blz.

Dit rapport is gratis te downloaden van https://doi.org/10.18174/443803 of op

www.wur.nl/environmental-research (ga naar 'Wageningen Environmental Research' in de grijze balk onderaan). Wageningen Environmental Research verstrekt geen gedrukte exemplaren van rapporten.

(C) 2018 Wageningen Environmental Research (instituut binnen de rechtspersoon Stichting Wageningen Research), Postbus 47, 6700 AA Wageningen, T 03174807 00, www.wur.nl/environmental-research. Wageningen Environmental Research is onderdeel van Wageningen University \& Research.

- Overname, verveelvoudiging of openbaarmaking van deze uitgave is toegestaan mits met duidelijke bronvermelding.

- Overname, verveelvoudiging of openbaarmaking is niet toegestaan voor commerciële doeleinden en/of geldelijk gewin.

- Overname, verveelvoudiging of openbaarmaking is niet toegestaan voor die gedeelten van deze uitgave waarvan duidelijk is dat de auteursrechten liggen bij derden en/of zijn voorbehouden.

Wageningen Environmental Research aanvaardt geen aansprakelijkheid voor eventuele schade voortvloeiend uit het gebruik van de resultaten van dit onderzoek of de toepassing van de adviezen.

Wageningen Environmental Research Rapport 2874 | ISSN 1566-7197

Foto omslag: Shutterstock 


\section{Inhoud}

$\begin{array}{ll}\text { Samenvatting } & \mathbf{5}\end{array}$

$\begin{array}{lll}1 & \text { Inleiding } & 7\end{array}$

$\begin{array}{llr}2 & \text { Beleidscontext } & 9\end{array}$

$\begin{array}{llr}3 & \text { Globale uitdagingen } & 11\end{array}$

$4 \quad$ Oplossingen op drie niveaus $r$

$\begin{array}{lrr}5 & \text { Actoren } & 20\end{array}$

$\begin{array}{llr}6 & \text { Regio's } & 23\end{array}$

$\begin{array}{llr}7 & \text { Relevante investeringsopties } & 26\end{array}$

$\begin{array}{ll}\text { Bronnen } & 35\end{array}$ 



\section{Samenvatting}

Nederland is goed in agrofood. Een van de sterke kanten is de verwevenheid van overheid, bedrijfsleven, kennisinstellingen en civil society organisaties, de Dutch Diamond. Met het onderschrijven van duurzaamheid- (SDG) en klimaatdoelen in het Regeerakkoord 2017-2021 heeft Nederland zich duidelijk gecommitteerd. In dit rapport wordt geanalyseerd op welke werkvelden de Nederlandse agrofoodsector, opgerekt tot de nexus landbouw-klimaat-water-voedselzekerheid, zich internationaal kan profileren, waarbij tegelijkertijd stappen worden gezet die de klimaat- en duurzaamheidsdoelen dichterbij brengen.

De analyse volgt op een vaststelling van de grote globale uitdagingen, zoals klimaatverandering, urbanisatie, jeugdwerkloosheid, voedselverliezen, toename van dierlijke consumptie en de concurrentie van landbouw met bos, natuur en biodiversiteit. Drie lijnen worden verder vastgehouden: werkvelden waar we al goed in zijn, maar waar snelle opschaling vereist is om met enig tempo op de doelen af te stevenen (productie, voeding, oogstverliezen terugbrengen, kennis opbouwen); werkvelden die deels nog in het innovatiestadium verkeren (veredelen op droogte en zout; circulaire economie creëren, groeiende steden voeden; efficiënte ketens ontwikkelen; slim met vierkante meters omgaan); werkvelden die onder het steeds breder gehanteerde begrip food systems vallen. Hier komt alles wat voedselproductie en -consumptie beïnvloedt bij elkaar. Zo veel mogelijk wordt aangegeven welke actoren (bedrijfsleven, kennisinstellingen, overheden, ngo's) actief zijn of kunnen worden en in welke delen van de wereld.

De groei van de wereldbevolking zal grotendeels in de steden van Afrika en Azië plaatsvinden, waarbij Afrika met afstand het jonge continent van de wereld is. Een centrale opgave zal dan ook zijn om de verwachte groei van de (arbeidsintensieve) agrofoodsector te koppelen aan werkgelegenheid voor jongeren in Afrika en delen van Azië. Hierbij zijn nieuwe food systems nodig waarbij de kleine boer(in) en zijn/haar farming system op een nieuwe manier verbonden worden met de stedelijke consument. Investeringen in de kennis en organisatie van jonge boeren, het versterken van landrechten en het verbeteren van de kwaliteit van de hele keten, inclusief hergebruik van reststromen, is de grootste opdracht. Daarnaast zal moeten worden voorkomen dat resterende arealen bos en natuur ten onder gaan aan de noodzaak meer voedsel te produceren. Efficiënte productie en gezonde voeding moeten bereikt worden op kleine arealen, waarbij de twee routes om klimaatverandering te lijf te gaan (mitigatie en adaptatie) zo veel mogelijk tegelijk worden geadresseerd. Er is veel werk aan de winkel waarbij Nederland een vooraanstaande rol kan spelen. Het succes zal bepalen of er niet na de Klimaattop ook een Voedsel- en Drinkwatertop nodig zal zijn. 


\section{$1 \quad$ Inleiding}

In 2050 moeten ruim 9 miljard mensen voorzien worden van goed voedsel en schoon drinkwater. Dat dit een enorme uitdaging is, is het eerste cliché van deze notitie. De voedselproductie moet tussen nu en 2050 met ongeveer $70 \%$ omhoog. Optimisten zien ons daarin slagen, zoals Louise Fresco in Hamburgers in het Paradijs (2012). Zij rekent op het menselijk vernuft om een dergelijke opgave tot een goed einde te brengen. Een alarmiste als Sara Menker ziet het daarentegen over 10 jaar al misgaan (https://qz.com/1064653/the-world-could-run-out-of-food-two-decades-earlier-thanthought/). Feit blijft dat we tegen die tijd, als we niet snel en slim handelen, met een vermoeide planeet zitten, met minder bos en natuur en waarvan de vruchtbare bodems zijn opgebruikt of weggespoeld. Ook hangt ons verdere klimaatverandering boven het hoofd. Kortom: er zijn drie taken tegelijk te vervullen om ook na 2050 een leefbare, veerkrachtige planeet over te houden die de generaties daarna kan bedienen. Dat gaat niet vanzelf. Het onderschrijven van de Sustainable Development Goals (SDGs) en het Klimaatakkoord van Parijs in 2015 door veel landen tekent het gevoel van urgentie. De komende jaren en decennia moet er boter bij de vis, met heldere precisering waar wat moet gebeuren, door wie, wat het kost en wie de rekening betaalt. Want ook hier gaat de kost voor de baat uit. Niet alleen overheden en $\mathrm{VN}$-instellingen hebben hier aan bij te dragen, maar ook de voedselproducent en -consument zelf en andere ketenpartners, financiële instellingen, het groot-, midden- en kleinbedrijf, ngo's en de kennisinstellingen. En dat op zeer verschillende plekken in de wereld. Dit zal in partnerschappen moeten gebeuren, zoals SDG 17 voorschrijft. De positie van Nederland is dermate prominent in de sectoren voedsel en water, dat een flinke bijdrage verwacht mag worden bij het aanpakken van de geschetste kwesties. Daarom: Dutch Solutions for Global Challenges in het agrofood-domein.

Het doel van deze notitie is om binnen beleidskaders een agenda-zettende impuls te geven aan een nieuwe, internationale agrofoodstrategie, gericht op het halen van de hierboven genoemde productie-, klimaat- en duurzaamheidsdoelen. Daarbij wordt gebruikgemaakt van de kanalen handel, investeringen, innovatie, kennisontwikkeling en hulp. Om meer dwarsverbanden te kunnen leggen, is agrofood opgerekt tot de nexus landbouw-klimaat-water-voedselzekerheid. Het stuk is in eerste instantie bedoeld voor landbouwraden, innovatie-attachés en andere staf van ministeries en ambassades die zich bewegen op de overlappende terreinen van Buitenlandse Zaken, Ontwikkelingssamenwerking en Landbouw, Natuur en Voedselkwaliteit. Een eerste poging het onderwerp zichtbaar en behapbaar te maken, werd gedaan tijdens de workshop 'Landbouw-klimaatwater-voedselzekerheid', op 30 oktober 2017 tijdens de Internationale Economie Week.

Het beleidskader wordt vormgegeven door een brief aan de Tweede Kamer van september 2016: Toekomstbestendige Agrofood Export (DGAN-ELVV / 1613987) en het Regeerakkoord 2017-2021. Relevante passages zijn opgenomen in hoofdstuk 2. Vervolgens worden tien grote uitdagingen benoemd in hoofdstuk 3 en wordt een antwoord gegeven op de vraag: Waarom is op deze terreinen actie vereist? In de overige hoofdstukken wordt de vertaalslag gemaakt van uitdaging naar relevante werkvelden (wat moet er gebeuren, wanneer, door wie, waar en hoe?). In hoofdstuk 4 vindt een rangschikking plaats volgens drie denk- en urgentieniveaus: wat ligt op de plank en kan meteen ter hand genomen en opgeschaald worden (niveau 1), welke innovaties moeten snel van het lab naar het veld (niveau 2) en hoe krijgen we het holistische concept food systems uitgewerkt, omarmd en op enige termijn breed ingezet (niveau 3)? Hoofdstuk 5 geeft een overzicht van het type actoren dat een rol speelt bij de Dutch Solutions, hoofdstuk 6 een overzicht van de accenten die in verschillende delen van de wereld gegeven zouden kunnen worden en in hoofdstuk 7 worden de werkvelden geconcretiseerd, door het gebodene in hoofdstuk 4, 5 en 6 met elkaar te verbinden. Dit leidt tot een set van terreinen waarop de Dutch Solutions for Global Challenges kunnen worden toegepast, enigszins gegroepeerd naar complexiteit en urgentie, naar actoren en naar werelddeel. Het beeld is hiermee verre van compleet, maar biedt hopelijk wel voldoende aangrijpingspunten voor de doelgroepen. 
Het betreft hier een eerste poging om tot een integrale, globale benadering/identificatie van Dutch Solutions voor Global Challenges te komen. Het is wellicht nuttig een verdiepingsslag te maken en te komen tot een menu aan opties voor regio's/combinaties van landen, met zowel themadeskundigen op ontwikkelingssamenwerking als landbouwraden. Dit met als doel beleidsmakers, bedrijfsleven, ngo's en landbouwraden/ambassades te ondersteunen in het zo goed mogelijk gebruikmaken van de potentie van de 'Dutch Diamond' bij het vormgeven van de agrofood-agenda en de knooppunten van landbouw, water, klimaat en voedselzekerheid. Een agenda voor deze Dutch Diamond staat centraal in een vrij recente publicatie van de Adviesraad Internationale Vraagstukken (https://aiv-

advies.nl/8j2/publicaties/adviezen/daadkracht-door-de-dutch-diamond-ondernemen-in-het-licht-vande-nieuwe-duurzame-ontwikkelingsdoelen).

Dank voor meedenken en commentaar gaat uit naar de volgende collega's van Wageningen University \& Research: Siemen van Berkum, Petra Berkhout, Jelle Maas, Henk van der Mheen, Derk Rademaker, Ruerd Ruben, Martin Scholten, Jan Verhagen en Saskia Visser. 


\section{Beleidscontext}

De uitdagingen waar de Nederlandse agrofood-export voor staat, werden door het kabinet-Rutte II in september 2016 verwoord in een brief aan de Tweede Kamer: Toekomstbestendige Agrofood Export (DGAN-ELVV / 1613987). Daarin wordt de bestaande kracht van het NL agrofood system toegeschreven aan (i) het vermogen integrale oplossingen aan te dragen, (ii) cross-sectoraal samen te werken, (iii) de nabijheid van een sterke primaire sector en (iv) het snel vinden van nieuwe oplossingen rond voedselketens. In de brief worden ook uitdagingen benoemd op het gebied van hoogwaardige, duurzame producten, veranderingen in mondiale landbouwpraktijken en voedingspatronen en een voedselaanbod dat gevarieerd, veilig en gezond is en geproduceerd kan worden met respect voor de natuur en de leefomgeving.

Met het aantreden van een nieuwe regering is sprake van een nieuwe beleidscontext die gestalte heeft gekregen in 'Vertrouwen in de toekomst', het Regeerakkoord 2017-2021. Hieronder worden de voor dit rapport relevante passages (cursief) uitgelicht.

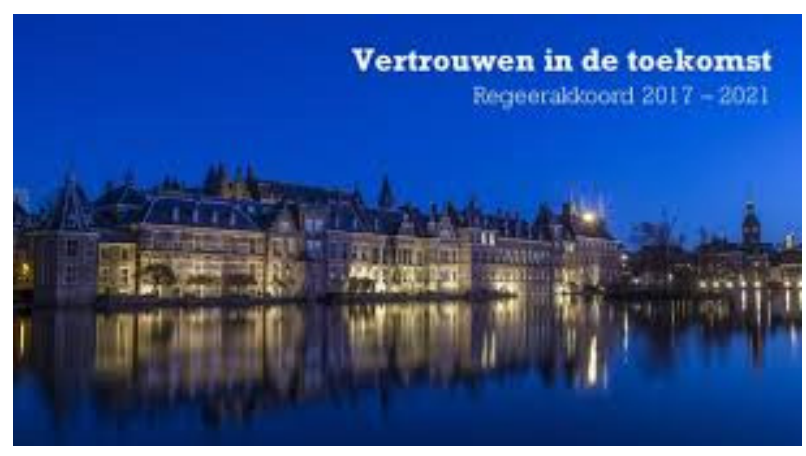

1. Het Regeerakkoord 2017-2021 noemt een verzameling internationale ambities die van betekenis zijn voor deze notitie. "We willen een actieve en betrouwbare internationale partner blijven en een voortrekker zijn in een slagvaardigere Europese Unie die de grote thema's van deze tijd aanpakt om burgers te beschermen. We dragen bijvoorbeeld bij aan welvaart en welzijn in andere landen en bestrijden zo ook de grondoorzaken van migratie. We voeren de klimaatafspraken van Parijs uit en we blijven ons inzetten voor vrede en veiligheid elders in de wereld. Ook helpen we Nederlandse innovatieve oplossingen en bedrijven de weg naar de wereld te vinden."

2. Op het terrein van landbouw kiest het Regeerakkoord ook een sterk internationale benadering: "Nederland is de tweede voedselexporteur ter wereld. Onze agro-foodsector kan een belangrijke bijdrage leveren aan een duurzame voedselvoorziening voor de groeiende wereldbevolking. Het beleid is erop gericht dit potentieel te benutten, binnen de geldende natuur- en milieunormen. Innovatie en ondernemerschap zijn daarbij cruciaal, net als aandacht voor de continuïteit van gezinsbedrijven, die een grote rol spelen in de sector. Innovatie moet ook onderdeel zijn van een eigentijds Europees Gemeenschappelijk Landbouwbeleid, net als duurzaamheid, voedselzekerheid en voedselveiligheid." Twee concrete kwesties worden specifiek genoemd: "Nederland zal zich in internationaal verband inzetten voor behoud van het kwekersrecht. Nederland zal zich in Europa inzetten voor toepassing en toelating van nieuwe veredelingstechnieken, zoals Crispr Cas9, mits daarbij geen soortengrenzen worden overschreden."

3. Ten aanzien van ontwikkelingslanden, noemt het Regeerakkoord een aantal specifieke zaken: "Seksuele en reproductieve gezondheid en rechten (SRGR), landbouw, water en rechtstaatbevordering zijn onderwerpen waarop Nederland van oudsher beleidsmatig belangrijke bijdragen levert. De speerpunten ten aanzien van armoedebestrijding blijven gericht op deze 
terreinen. Er komt binnen de begroting voor Ontwikkelingssamenwerking een nationaal klimaatfonds om het rendement van de internationale afgesproken publieke en private klimaatfinanciering zo groot mogelijk te maken. De inzet van het Nederlands maatschappelijk middenveld en het bedrijfsleven wordt voortgezet vanwege de specifieke expertise en het bereik. De IMVO (internationaal maatschappelijk verantwoord ondernemen)-convenanten worden voortgezet. Na twee jaar wordt bezien of, en zo ja welke, dwingende maatregelen genomen kunnen worden."

4. Het Regeerakkoord refereert ook aan de Sustainable Development Goals.

"Ontwikkelingssamenwerking is, als integraal onderdeel van het buitenlands beleid, gericht op de bestrijding van de grondoorzaken van armoede, migratie, terreur en klimaatverandering. Dat gebeurt binnen de duurzame ontwikkelingsdoelstellingen van de Verenigde Naties."

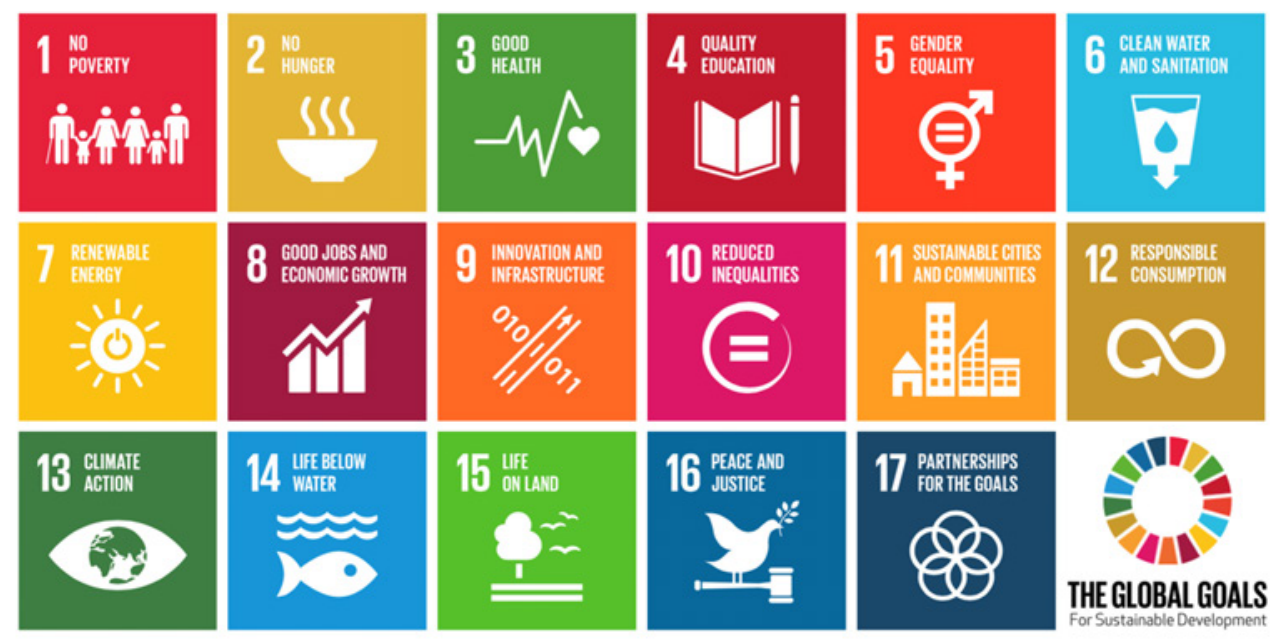

5. Het door Nederland bij wet geratificeerde Parijs-akkoord en de bijdrage aan internationale actie op het terrein van klimaatverandering wordt als volgt verwoord: "We maken werk van een ambitieus klimaatbeleid. Nederland wordt duurzaam. We hebben geen alternatief voor aanpakken. We nemen onze verantwoordelijkheid voor het klimaatakkoord van Parijs. Er komt een nationaal Klimaat- en energieakkoord waarmee we met alle partijen de $\mathrm{CO}_{2}$-uitstoot fors gaan verlagen. Denk daarbij aan verduurzaming van de gebouwde omgeving en het verkeer, vergroening van ons belastingstelsel en nieuwe energiebronnen. We leggen de lat hoog. We willen de ambitieuste doelstelling van Parijs. Daarvoor werken we samen met gelijkgezinde landen in Europa."

6. Ook de overgang naar een circulaire economie wordt expliciet genoemd: "Als onderdeel van de klimaatopgave worden de afspraken uit het rijksbrede programma circulaire economie en de transitieagenda's uit het Grondstoffenakkoord uitgevoerd. Daarbij legt het kabinet een extra accent op ontwikkeling en verspreiding van kennis en best practices. Het kabinet inventariseert tevens welke knelpunten in regelgeving, toezicht en handhaving duurzame innovaties in de weg staan en hoe deze mogelijk opgelost kunnen worden." 


\section{Globale uitdagingen}

\section{Nexus landbouw-water-klimaat-voedselzekerheid}

Landbouw is in veel landen nog altijd de motor achter economische groei en voorlopig ook nog de grootste bron van werkgelegenheid. Het Wereldbank-rapport Enabling the business of agriculture 2017 vermeldt dat landbouw vijf keer zo effectief is als andere sectoren in armoedebestrijding. Er is een permanente druk op de productie om de consumptie bij te houden en dat blijft zo tot 2050. Toch ligt de productie soms nog aanzienlijk beneden de potentiële niveaus. Daar ligt ook de sleutel om de in 2050 noodzakelijke productie toch te halen. Dat dat niet al gebeurt, is samen te vatten onder 'een gebrek aan positieve prikkels voor de boer om de productie op te voeren'. De oorzaak kan voor in de keten liggen (slecht zaaizaad, verkeerde kunstmest), maar ook achter in de keten (geen toegang tot markten, problemen met houdbaarheid, belemmerende exporteisen). Veel boeren in ontwikkelingslanden zijn nog slecht verbonden met elkaar en met stedelijke markten en exportmarkten. Het areaal dat direct voor menselijke voeding wordt gebruikt, krimpt als gevolg van droogte, erosie en verzilting, maar ook door de productie van veevoeders, non-food crops en uitbreiding van steden en infrastructuur. Per persoon daalt de hoeveelheid beschikbaar landbouwland naar 0,2 ha in 2050 .

Op het terrein van klimaat is de wereld te verdelen in regio's die droger of natter en kouder of warmer worden. Men kan zich hier enigszins op instellen zolang het proces zich niet plotseling voordoet. Sommige processen hebben 'positieve feedbacks', zoals het smelten van permafrost in de bodems van de toendra's. Dit leidt tot enorme extra $\mathrm{CO}_{2}$-productie door afbraak van de ontdooide bodemorganische stof. Het smelten van gletsjers op de Himalaya is één ding, maar het vormt een directe bedreiging voor heel landbouwend en waterdrinkend Zuid- en Zuidoost-Azië. Een mogelijk catastrofale tipping point is wanneer de Warme Golfstroom besluit ermee op te houden (zoals uitgebeeld in de weinig subtiele film The day after tomorrow). De korte termijn geeft meer directe problemen die we al merken: de toename van de frequentie van hitte, droogte, overstromingen, verzilting in delta's en maandelijkse en jaarlijkse neerslagtotalen die ver afwijken van het langjarig gemiddelde, leidt steeds vaker tot misoogsten, menselijk lijden en grote materiële schade. Voedselproductie is verantwoordelijk voor ongeveer een kwart van de uitstoot van broeikasgassen. Met name de veehouderij en landgebruiksveranderingen, zoals boskap, dragen hieraan bij. Een onderzoek dat recent in Nature Climate Change gepubliceerd is, beargumenteert dat het veranderen van wereldwijde voedselsystemen cruciaal is om klimaatverandering te vertragen. De oplossing moet daarbij meer van de consument komen en van het terugdringen van voedselverliezen dan van productiviteitsverhoging of van areaaluitbreiding. Klimaatverandering werkt dan ook weer negatief door op de voedselproductie. Waar $14 \%$ groei per 10 jaar nodig is om de noodzakelijke graanopbrengsten in 2050 te halen, worden aanzienlijke oogstdalingen voorspeld in sommige regio's, met name in het Midden-Oosten en op het zuidelijk halfrond. Dit laatste is extra problematisch, omdat het zuidelijk halfrond relatief weinig landmassa heeft en wel elk halfjaar moet leveren om geen grote schommelingen in de mondiale voedselvoorraden en -prijzen te veroorzaken. 


\section{Increasing challenge from climate change}

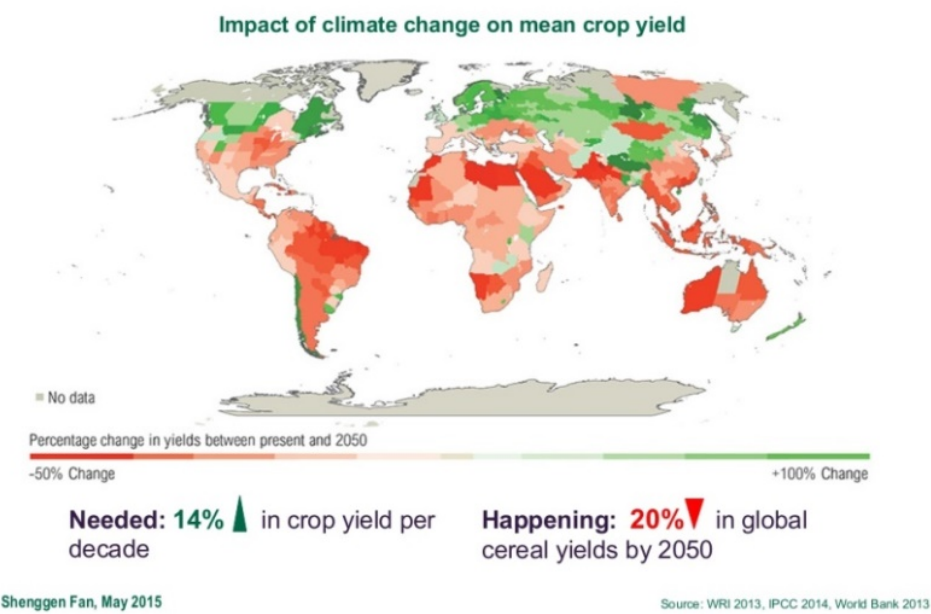

Wat betreft water dreigen voorraden zoetwater op te raken, verdrogen rivieren in semi-aride regio's, zoals het Midden-Oosten en Noord-Afrika (MENA regio), en ontstaat de noodzaak waterputten steeds dieper te moeten slaan of fossiel water op te pompen. Ook raken zoetwaterreserves vervuild door bestrijdingsmiddelen. Tekorten aan water bedreigen ook de voedselproductie. Wereldwijd komt bijna $40 \%$ van geïrrigeerde akkers. Water gebruikt voor irrigatie gaat in toenemende mate concurreren met andere benutting van hetzelfde water. Uit schattingen van de Verenigde Naties blijkt de behoefte aan zoetwater de komende decennia met $50 \%$ te stijgen als gevolg van de groei van wereldbevolking en welvaart. Op dit moment heeft een miljard mensen geen toegang tot veilig drinkwater en bijna de helft van de bevolking heeft regelmatig te maken met watertekorten.

\section{Growing land and water constraints}
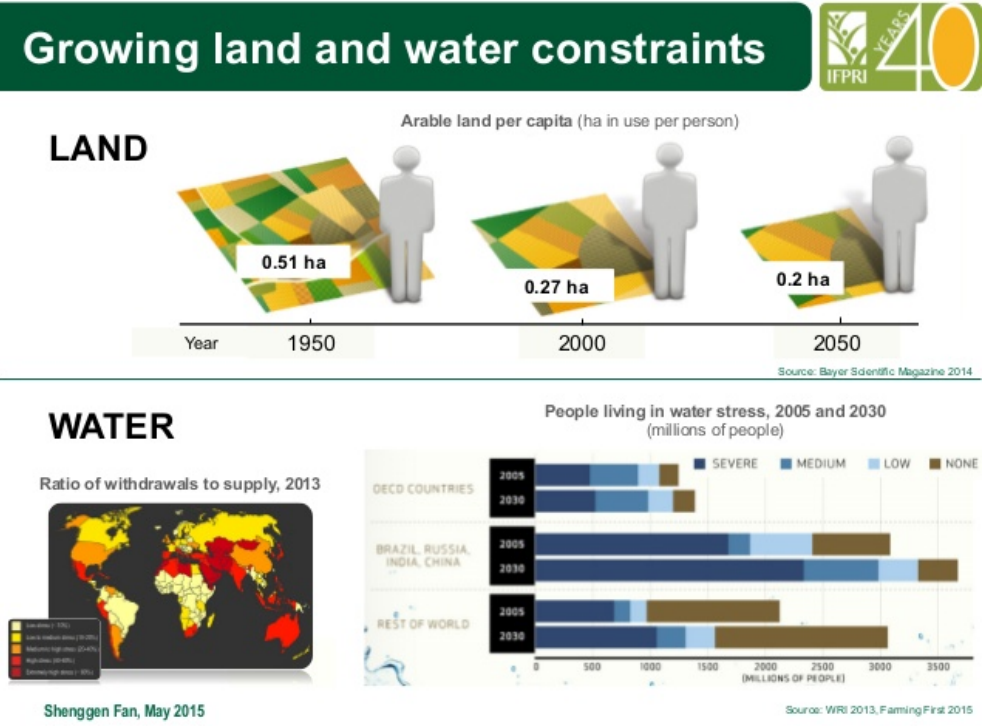

Ten aanzien van voedselzekerheid ligt de uitdaging met name bij ondervoeding van het jonge kind (eerste 1000 dagen) en de negatieve effecten daarvan op latere leeftijd. Vooral onevenwichtige voeding (gebrek aan micronutriënten) is een probleem in Afrika en India. Aan de andere kant van het spectrum worden overgewicht en obesitas steeds meer een probleem. Waar 800 miljoen mensen ondervoed zijn, zijn er ruim twee miljard mensen te dik of obees. Dit is niet meer een puur westers probleem. Elders in de wereld is de stijging aanzienlijk, met name in steden. 


\section{Multiple burdens of malnutrition persist}

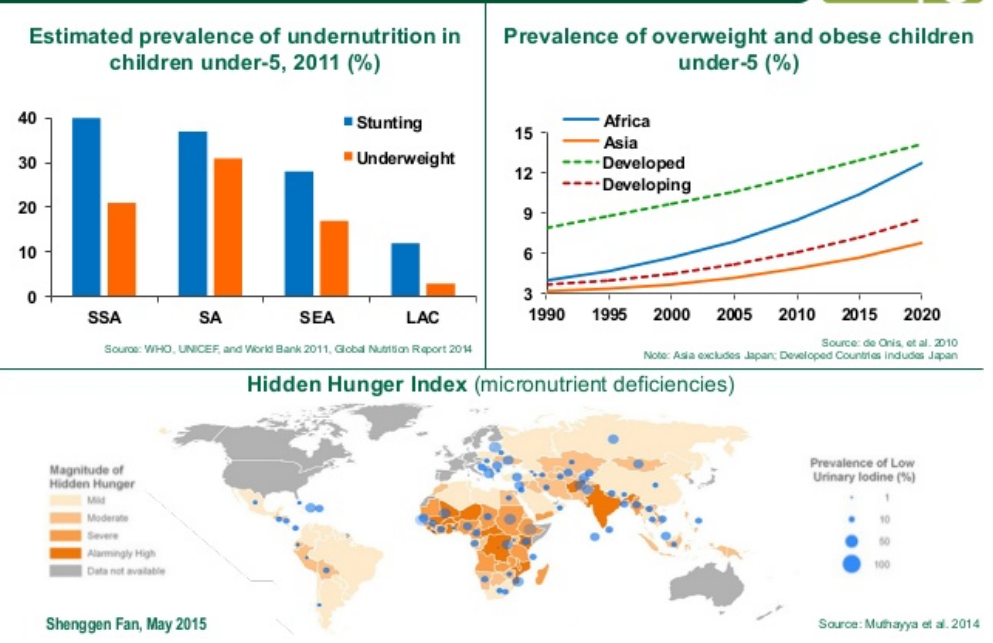

\section{Voedselverliezen}

Wereldwijd gaat een derde van de totale voedselproductie verloren voordat het de consument bereikt. De verschillen zijn groot: in Noord-Amerika gaat het om $42 \%$, in Zuid-Amerika om $15 \%$. In NoordAmerika betreft meer dan de helft van de verliezen afval op de veiling en aan de dinertafel, terwijl in Azië en Afrika meer dan de helft het gevolg is van directe oogstverliezen op het veld of tijdens transport en opslag. De voedselverliezen vertegenwoordigen een jaarlijkse waarde van ruim 500 miljard euro. De Nederlandse keten van producenten, tussenhandel, horeca, supermarkten en consument verspillen ongeveer 4 miljard euro aan voedsel per jaar. 5 tot $10 \%$ van de groente en het fruit wordt bijvoorbeeld afgekeurd vanwege strenge eisen aan het uiterlijk van het product. Opgemerkt dient te worden dat de schattingen over verliezen uiteenlopen, IFPRI zit een stuk lager dan FAO.

Figure 1. Food loss and waste occurs more 'near the fork' in developed regions and more 'near the farm' in developing regions (Percent of kcal lost and wasted)

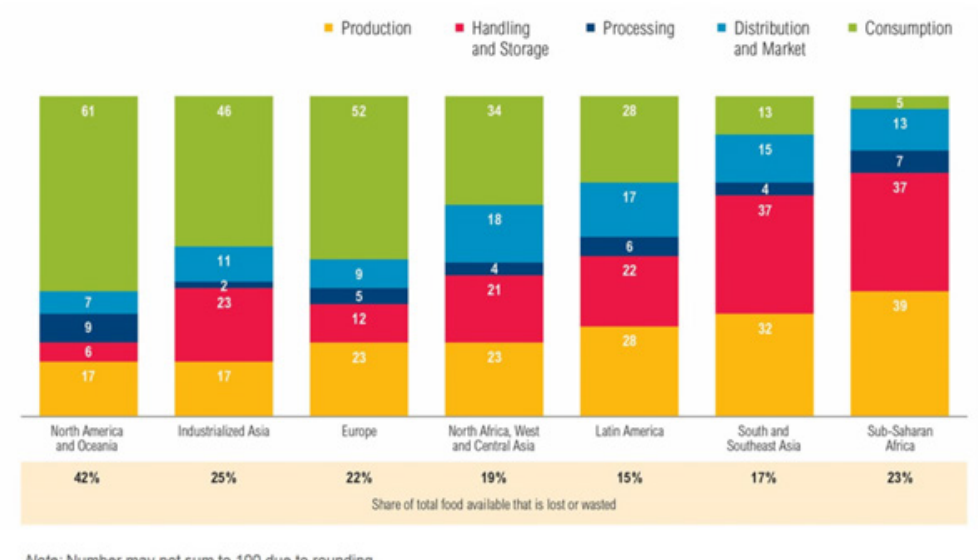

Note: Number may not sum to 100 due to rounding.

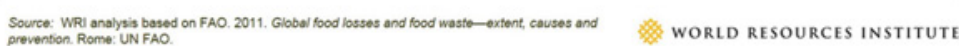

\section{Urbanisatie}

Steeds meer mensen zullen in 2050 in steden wonen. De groei in Azië en Afrika zal enorm zijn. Op het moment is de verhouding ruraal : urbaan ongeveer $1: 1$, maar in 2050 zal dit $1: 2$ zijn. Dit betekent dat veel meer mensen voor de aanvoer van voedsel en drinkwater afhankelijk zijn van productie elders en goed functionerende diensten en markten die zorgen dat ze bereikbaar en betaalbaar zijn. Aangezien sociale onrust vaak in steden begint, is deze uitdaging niet alleen een technische kwestie, maar ook een politieke noodzaak. 


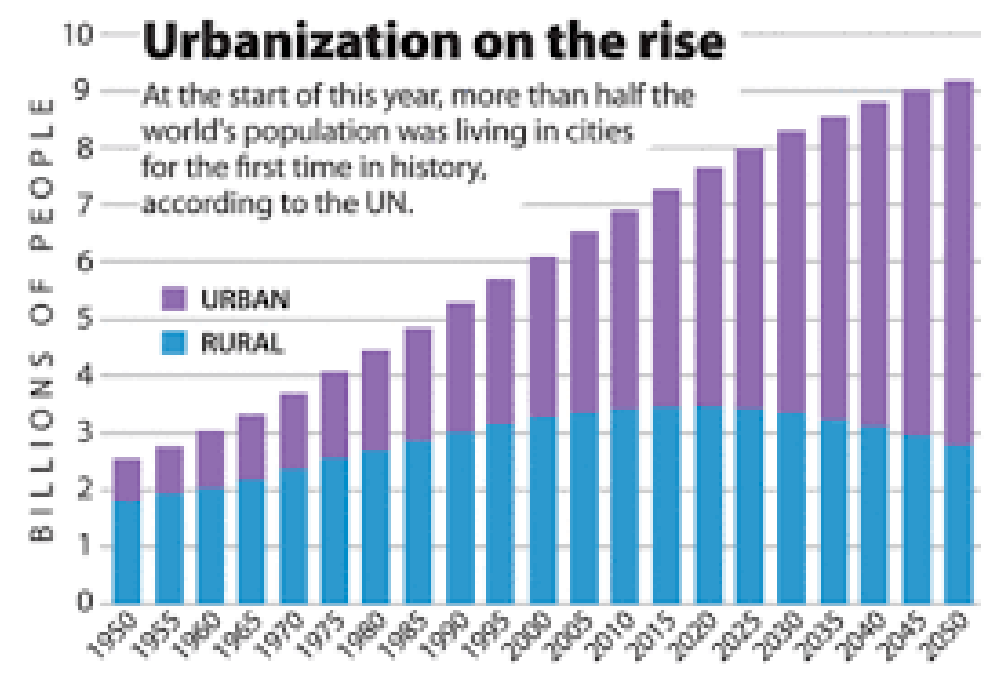

\section{Van dierlijke naar plantaardige eiwitten}

Toenemende welvaart vertaalt zich ook in verandering van eetpatronen. Steeds meer mensen eten of drinken dierlijke eiwitten. Voorspelde procentuele toenames zijn zeer hoog, vooral in landen-inopkomst en ontwikkelingslanden. Een inwoner van de VS at in 2009 1,5 keer zoveel vlees als een inwoner van de EU, maar die at weer bijna twee keer zoveel vlees als een Zuid-Afrikaan. Dierlijke productie legt een groter beslag op land dan plantaardige productie. Slechts een gering deel van de voeding van de plant komt via het dier in de mens terecht. Veel gaat tussentijds verloren. Het areaal diervoeders groeit hard (soja, maïs, graslanden) en in veel gebieden leidt overbeweiding tot erosie en het wegspoelen van vruchtbare grond. Dieren stoten methaan $\left(\mathrm{CH}_{4}\right)$ uit, wat een schadelijker broeikasgas is dan $\mathrm{CO}_{2}$. Anderzijds zijn dieren vaak goed te houden in gebieden waar landbouw niet mogelijk is en eten ze restproducten die anders zouden worden weggegooid.

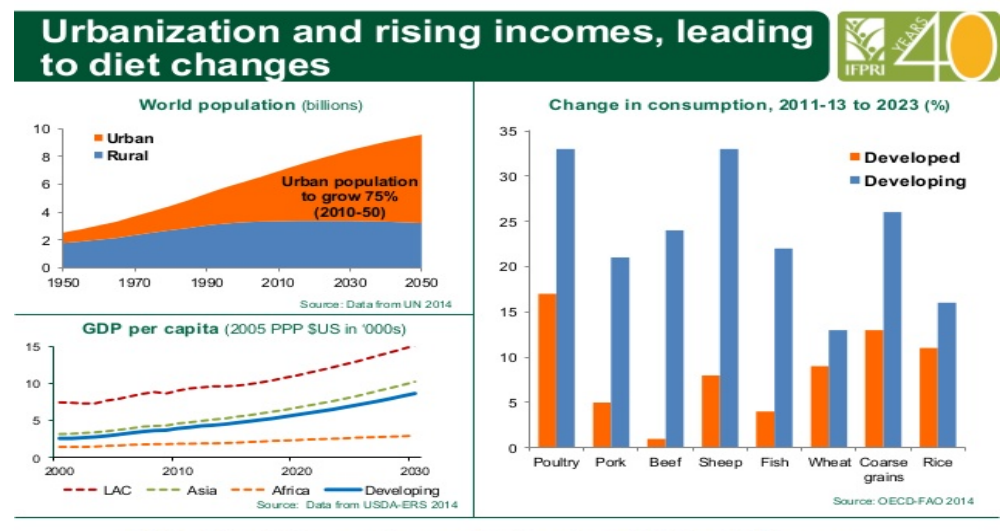

Global food demand expected to rise $60 \%$ by 2050 (FAO 2012) Shenggen Fan, May 2015

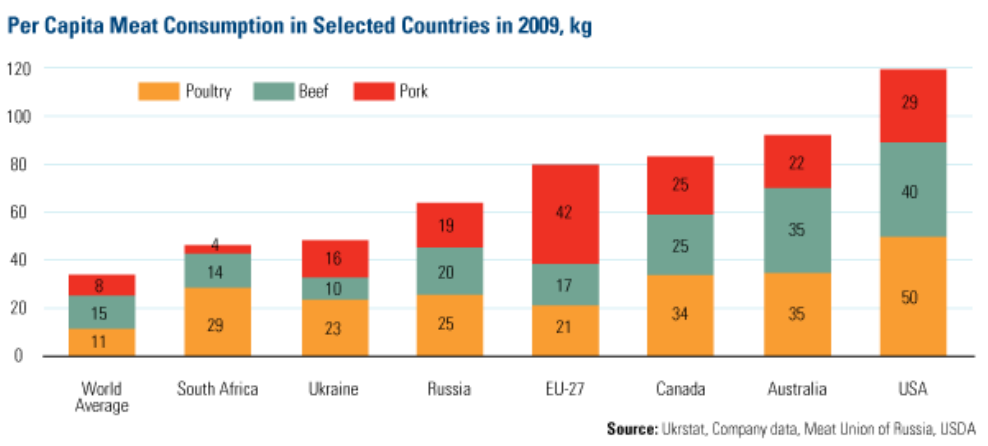




\section{Voedselveiligheid}

Dit onderwerp komt wereldwijd steeds prominenter op de agenda, in verschillende gedaantes. Er is enerzijds een toename aan ziektes en plagen die gerelateerd zijn aan landbouw, veehouderij en water. Het gaat hierbij om ziektes bij planten die landbouwgronden tijdelijk ongeschikt maken voor een gewas (bv. Phytophtera bij aardappel), om ziektes bij dieren die in hoge mate besmettelijk zijn en in geval van zoönosen (bv. Q-koorts) op de mens kunnen overspringen of om ziektes bij de mens door onbeschermd contact via huid of lucht met kunstmest of bestrijdingsmiddelen. Preventief gebruik van antibiotica en andere medicijnen in de dierhouderij leidt tot resistentierisico's en milieuvervuiling. Tegelijkertijd ontstaat er steeds meer aandacht voor voedselveiligheid en worden strenge, wettelijke eisen gesteld aan producten die uit de schappen verdwijnen, maar daarmee ook aan producten die geïmporteerd worden van elders. Dit leidt geregeld tot (fyto)sanitaire conflicten en al dan niet voldoende onderbouwde eisen over de kwaliteit van producten. Ook zaken rond intellectueel eigendom van uitgangsmaterialen en de aanwending en toelating van gentechproducten zijn zeer verschillend geregeld in de wereld en vaak onderwerp van politiek en maatschappelijk debat.

\section{Rising agriculture-related risks to health}

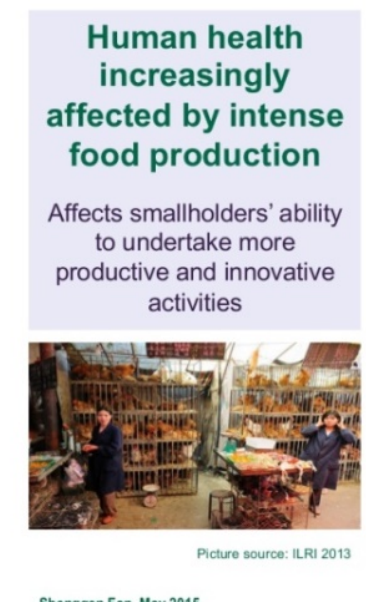

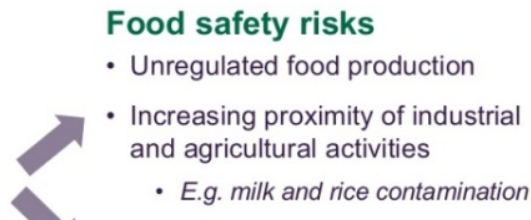

- E.g. milk and rice contamination

Animal-borne diseases

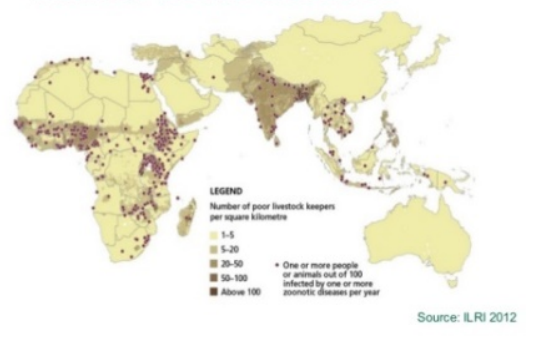

\section{Van producent naar consument}

Traditioneel zijn wij geneigd de productie als uitgangspunt te nemen, omdat die mede de omzet bepaalt. Het is noodzakelijk om veel meer vanuit de verschillende typen consument te gaan denken. Het opgetelde eetgedrag van de mens moet het richtpunt zijn en de interventies daarvan afgeleid. Tonnen per hectare is daarin een belangrijke schakel, maar raakt niet aan de kern. De consument is te verdelen in een urbane middle en upper class, die bediend worden via supermarkt, cateraar en restaurant door grotere multinationale ondernemingen met lange verticale ketens, een rurale lower class die het moet hebben van korte ketens en lokale openlucht markten en een grote intermediate groep, vooral in Azië. Deze groep wil in toenemende mate anders bediend worden op de voedselmarkt. Een deel van die groep eist duurzaamheid, maar een groot deel wil de toegenomen welvaart omzetten in een nieuwe eetcultuur. Er zijn investeringen nodig in de aansluiting van rurale productie op urbane wensen.

\section{Van lineaire naar circulaire economie}

Het afsluiten van een uiterst consumptieve periode in de westerse samenleving gaat gepaard met het inzicht dat grondstoffen schaars worden of opraken. Los van de bedreiging van een tekort aan een noodzakelijke grondstof, kan een land of regio die ze nog bezit ze inzetten voor politieke doelen. Er is mede hierdoor alle reden om vol in te zetten op de overstap van een lineaire naar een circulaire economie. In de context van dit rapport gaat het dan om het recyclen van voedsel- en nutriëntenstromen en producten die gebruikt worden in het food system, dus ook verpakkings- en andere materialen. Hergebruik van organisch afval heeft dikwijls ook een bijvangst in de vorm van biogas. 


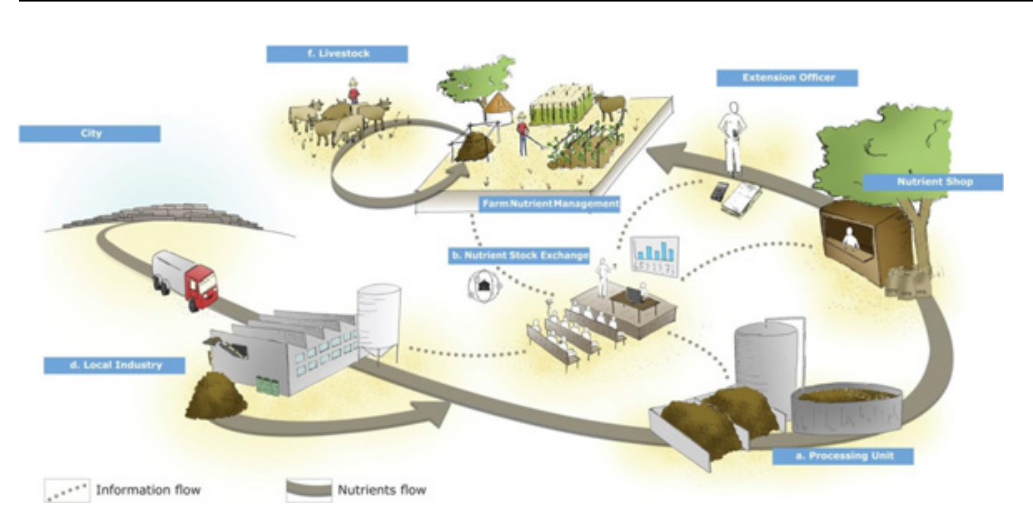

\section{Bos, natuur en biodiversiteit}

De belangrijkste hectare-concurrent van de landbouw staat wereldwijd onder druk. Metingen van het areaal bos en natuur in absolute zin geeft een gemengd beeld, met groei hier en afname daar. Toch lopen met name de grote tropische regenwouden gevaar (door de palmolieproductie in Zuidoost-Azië en de sojateelt in Zuid-Amerika) en zijn veel savannes al omgezet in landbouwland. Overal staat de biodiversiteit onder druk. Er is veel internationale aandacht voor, maar de achteruitgang zet gestaag door. Daarnaast lukt het onvoldoende om in gebieden met intensieve landbouw de kwaliteit van natuurlijke ecosystemen voldoende op peil te houden. Ook in Europa is dit een worsteling op grond waarvan het Natura 2000-netwerk is ingericht. In algemene zin is te stellen dat aan ecosystem goods, zoals voedsel, drinkwater en hout een hogere economische waarde wordt toegekend dan aan ecosystem services, zoals biodiversiteit en bescherming van de bovenstroomse delen van stroomgebieden, die vaak de watertorens zijn van bewoonde regio's.
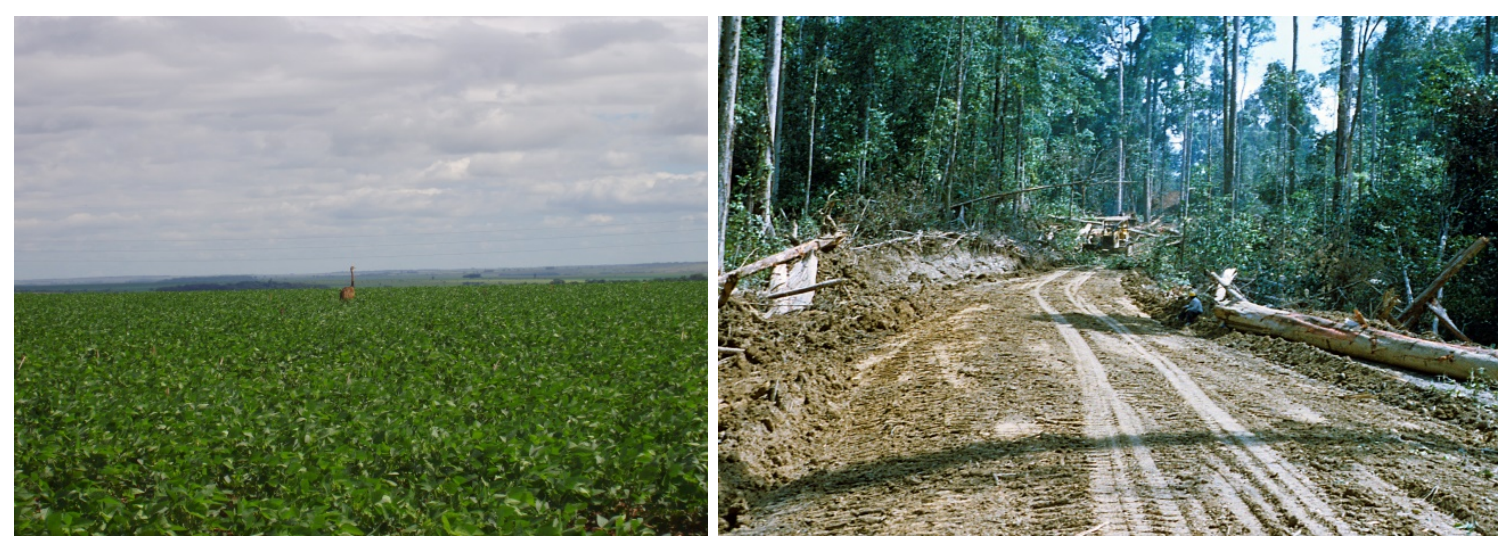

\section{Landrechten en landgebruiksconflicten}

Land is altijd van iemand, maar niet altijd van degene die er landbouw op bedrijft. Conflict om land speelt steeds vaker een rol daar waar het drukker wordt. De vestiging van bedrijven of bijvoorbeeld windenergieprojecten in gebieden met een bevolking die geen formeel recht kan doen gelden op hun grond leidt tot conflicten die blijvende onvrede veroorzaken, ondanks de werkgelegenheid die vaak wordt gecreëerd. Ook komen landbouw, veehouderij, natuur- en wildparken en bebouwing steeds vaker in elkaars vaarwater. Goede kadastrale systemen kunnen een deel van de problemen wegnemen, maar in veel gebieden heeft land ook een sterk spirituele betekenis die niet zomaar is weg te poetsen met een papieren transactie.

\section{Jeugdwerkloosheid}

Dit probleem is groter dan de agrofoodsector, en geldt met name in Afrika. Het is gekoppeld aan de migratiedruk, die in deze tijd tot allerlei uitwassen leidt: van verdrinking tot slavernij en van mensensmokkel tot weerstand in Europese landen. Voor deze studie is van belang dat over het algemeen de landbouw vergrijst en de werkgelegenheid in de landbouw afneemt. Leegloop van het platteland en urbanisatie zorgen echter dat meer mensen niet zelf in hun voedsel kunnen voorzien en dit wel moeten kunnen blijven betalen. In sommige gebieden biedt de stad economisch perspectief en 
is de uittreding positief gemotiveerd; in andere gebieden is het landbouwareaal dusdanig versnipperd dat er niets meer te verdelen valt en in weer andere gebieden kiezen jongeren niet meer voor een toekomst als jonge boer. In meer algemene zin is een politiek en militair conflict niet de enige reden voor mensen uit Afrika en Azië om naar andere werelddelen te migreren. Het is ook een gebrek aan perspectief op een arbeidzaam leven van voldoende kwaliteit. De toenemende vraag naar voedsel en water tussen nu en 2050 biedt in principe grote mogelijkheden om juist in die sectoren werkzaam te worden, maar dan wellicht op een andere manier dan het traditionele harde werk op de kleine akker. Hier ligt duidelijk een sleutel.

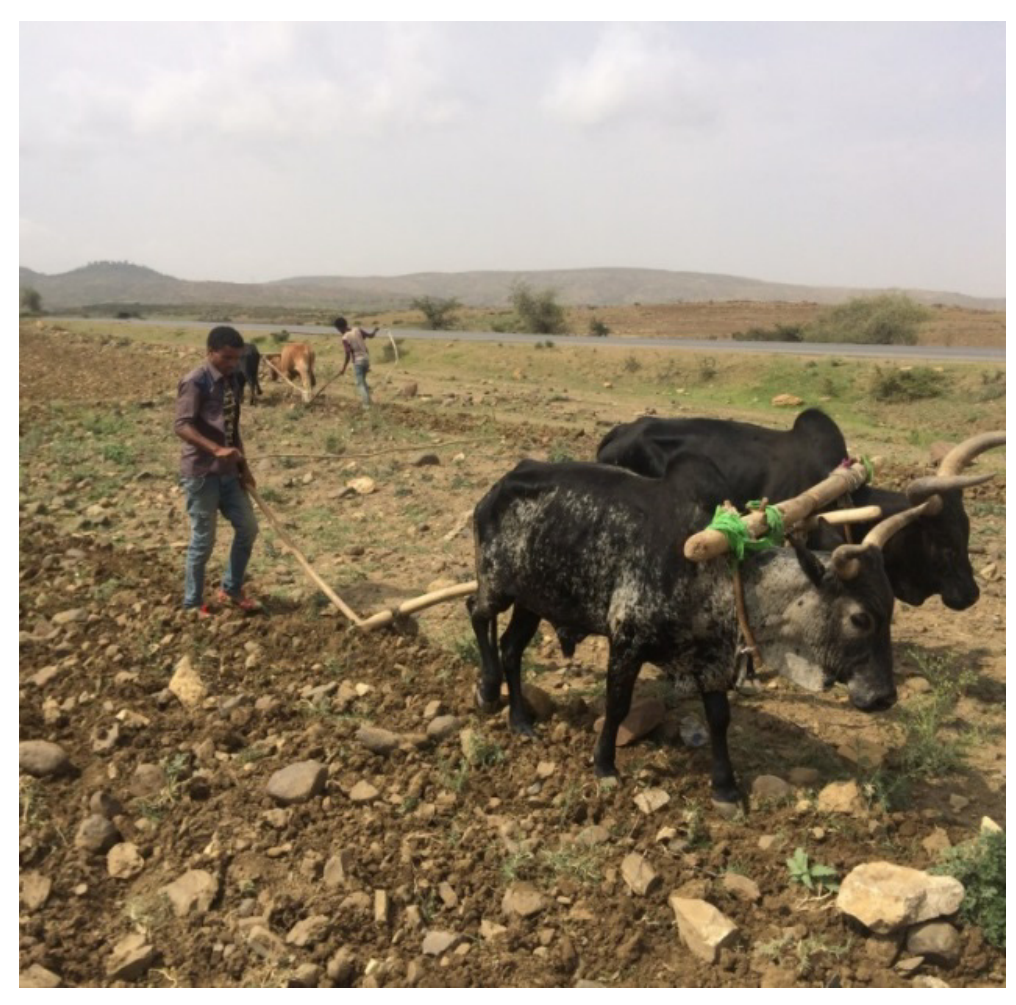

Samenvattend kunnen we stellen dat deze tien globale uitdagingen het speelveld vormen voor handel, hulp, kennisdeling, investeringen en interventies in de agrofoodsector. Het komt er nu op aan de analyse te verfijnen per regio, de juiste knoppen te vinden om aan te draaien zodat het food system gaat lopen en de juiste partnerschappen te ontwikkelen om het te realiseren. Hieronder volgt een poging daartoe. 


\section{$4 \quad$ Oplossingen op drie niveaus}

Drie denk- en urgentieniveaus worden gehanteerd. Er staan geen harde schotten tussen deze niveaus. Niveau 1 betreft vooral adoptie en opschalen van beschikbare technieken in bestaande landbouw- en voedingssystemen en is gericht op het dichten van voor de hand liggende gaten op het gebied van voedselproductie, voedingskwaliteit en het tegengaan van verliezen. Ook de formele en informele kennisoverdracht bevindt zich hier. Urgentie: 'nu doorpakken'. Voor niveau 2 wordt gebruikgemaakt van product- en systeeminnovaties en integrale benaderingen waarbij de begrippen climate smart en circulair centraal staan. Dit is een terrein dat uit de conceptuele fase groeit en de komende jaren tot volle bloei moet komen. Urgentie: 'van het lab naar het veld'. Niveau 3 gaat uit van het holistische voedselproductiesysteem waarbij alle aspecten worden meegewogen, van het bewerken van de grond tot het weggooien van de etensresten. Dit terrein vergt nog verdere ontwikkeling en inbedding in internationaal beleid. Vers van de pers is een fundamentele analyse van deze benadering door Van Berkum et al. (2017). Urgentie: 'concepten verbeteren en delen, pilots starten'.

Niveau 1 is te omschrijven als getting the basics right. Centraal staan hier de vragen (i) welke productiegaten zijn met bestaande technieken te dichten en (ii) wat is de schaalbaarheid van zulke technieken? Het betreft met name de volgende onderwerpen:

- realiseren van hogere opbrengsten en dan vooral de opbrengst per hectare, per eenheid water, kunstmest en ziekte- en plaagbestrijding (sluiten van yield gaps). Nevendoel is de extra productie zo veel mogelijk te realiseren op bestaand landbouwareaal, zodat bos, natuur en biodiversiteit gespaard blijven.

- verhogen van de voedselkwaliteit, met name op de voedingswaarde voor kinderen (eerste 1000 dagen) en voldoen aan wensen en -eisen op het gebied van voedselveiligheid.

- tegengaan en verminderen van oogstschade en voedselverliezen door verbeterde agrologistiek; hieronder vallen bijvoorbeeld ook gewasverzekeringen en andere financiële mechanismen om met schade om te gaan.

- opbouwen en delen van kennis en voorlichtingscapaciteit via formele en informele routes, het sluiten van functionele partnerschappen zoals coöperaties en het ontwikkelen van werkvormen tussen boer en bedrijf (cocreatie).

Niveau 2 herbergt innovaties die de komende jaren van het lab naar het veld moeten. Dit proces is al gaande, maar heeft zowel sturing als vaart nodig. Kernbegrippen zijn climate smart en circulair. Verschillende integrerende concepten staan hier centraal: ketenanalyses uitvoeren en interveniëren op de juiste punten, waarde toevoegen aan reststromen, life cycle-analyses van stoffen en nutriënten, beter begrip van beslissingen van primaire producenten als reactie op innovaties, de juiste stappen zetten tussen verschillende ruimtelijke en temporele schaalniveaus (van perceel naar bedrijf naar stroomgebied, van dit groeiseizoen naar 2050). Ook het 'nexus-denken' staat centraler op niveau 2, wat zich vertaalt in meervoudig landgebruik, synergie en meekoppelkansen tussen de bouwstenen van landbouw, water, klimaat en voedselzekerheid.

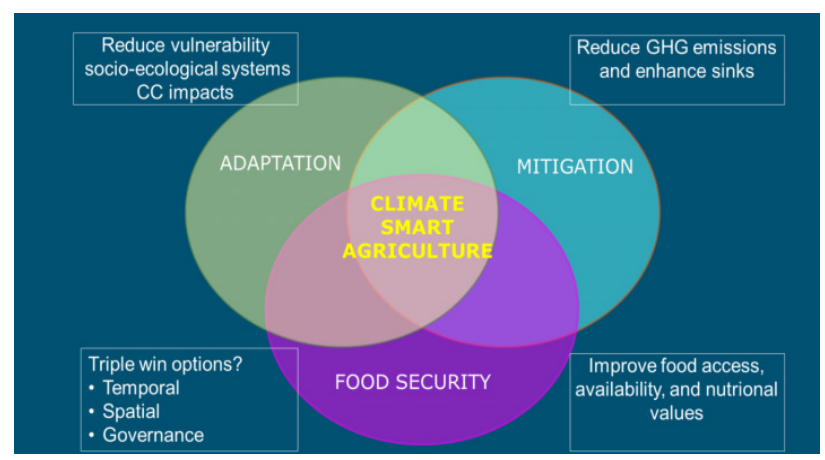


Niveau 3 is gericht op het steeds breder omarmde begrip food systems. Van Berkum et al. (2017) vatten het als volgt samen: 'Een voedselsysteembenadering (VSB) is een nuttig interdisciplinair denkkader voor onderzoek en beleid gericht op duurzame oplossingen voor voldoende en gezond voedsel. De VSB analyseert de relaties tussen de verschillende onderdelen van ons voedselsysteem en de uitkomsten van activiteiten in het voedselsysteem op sociaaleconomische en milieu/klimaatterrein. Een onderscheidende factor van systeemdenken zijn terugkoppelingen: tussen onderdelen van de voedselketen (productie, verwerking, distributie en consumptie) en van sociaaleconomische en milieuuitkomsten (zoals, respectievelijk, voedselzekerheid en bodemuitputting) van voedselproductie en verbruik weer terug naar die productie en het verbruik. Het VSB verschaft inzicht in niet-lineaire processen in het voedselsysteem en in mogelijke trade-offs tussen beleidsdoelen. Daarnaast verbreedt systeemdenken het perspectief bij het zoeken naar oplossingen voor de (kern)oorzaken van bijvoorbeeld armoede, ondervoeding en klimaatverandering. Het raamwerk heeft ten minste drie voordelen. Ten eerste reikt het een checklist aan voor de onderwerpen die in ieder geval aan de orde moeten komen als het gaat om verbeteren van voedselzekerheid, zeker in relatie tot andere beleidsdoelen. Ten tweede helpt het concept om de effecten van milieu- en klimaatveranderingen op voedselzekerheid in kaart te brengen door te wijzen op verschillende kwetsbaarheden van het voedselsysteem. In die zin kan het concept bijdragen aan het zoeken naar mogelijkheden die de weerbaarheid van het systeem tegen klimaatveranderingen kunnen versterken. En ten derde helpt het om de meest beperkende factoren voor het bereiken van voedselzekerheid te bepalen, en daarmee om effectieve interventies gericht op verbetering van voedselzekerheid te identificeren.' Dit niveau is het meest holistisch en complex, maar bij goede analyse en besluitvorming ook de meest optimale, efficiënte en inclusieve. Omdat aan dit onderwerp een aparte studie wordt gewijd (Van Berkum et al.), blijft het hier beperkt tot een algemeen betoog. De benadering wordt in veel gremia gepropageerd als denkkader, internationaal, door de relevante ministeries, door de topsector en door het PBL.

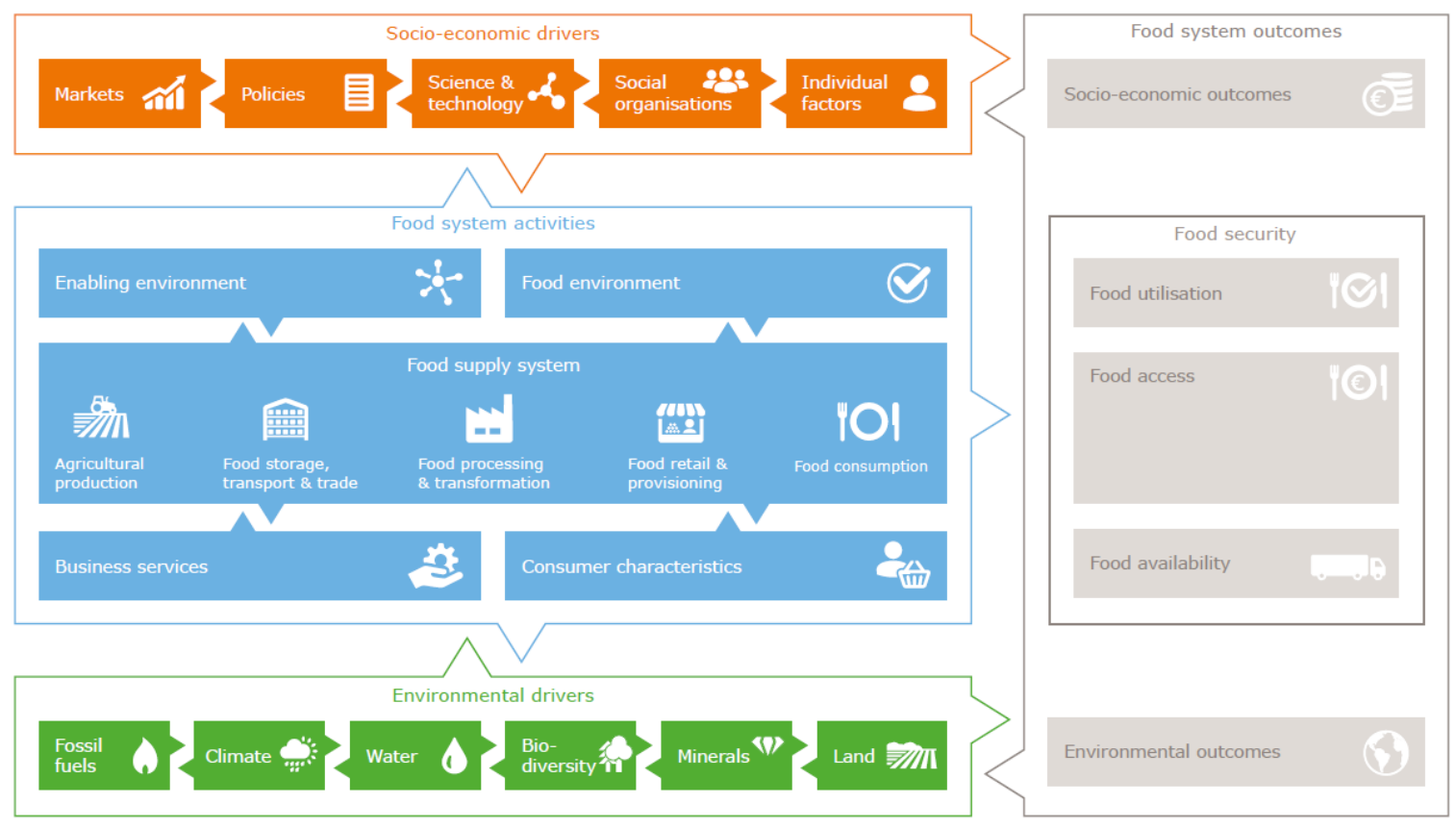




\section{Actoren}

\section{Duurzame export}

De Nederlandse agrofoodsector staat er op basis van cijfers goed voor. In 2016 was de export van agri \& food bijna 94 miljard euro, ten opzichte van 90 miljard in 2015 . Hiervan was 85 miljard euro aan agrarische producten en bijna 9 miljard aan landbouwmaterialen, -kennis en -technologie; een nieuw record. Daarmee is de agri \& food-sector goed voor $22 \%$ van de totale export. De export betreft voornamelijk voedsel, zoals groente, fruit, zuivel, vlees en bewerkte producten, en daarnaast ook hoogwaardige sierteelt. Opvallend is ook de toenemende vraag naar Nederlandse landbouwmaterialen, -innovaties en hoogwaardige technologie. Hiervan is voor bijna 9 miljard euro geëxporteerd. Het gaat dan bijvoorbeeld om energiezuinige kassen, systemen voor precisielandbouw (via gps en drones) en nieuwe vindingen, waardoor gewassen beter bestand zijn tegen gevolgen van klimaatverandering en ziektes. De export van kasmaterialen nam het sterkst toe (+ 370 miljoen euro). Daarmee wordt er voorzichtig opgeschoven richting export van kennis en innovaties die helpen bij het verduurzamen van de wereldvoedselproductie. Dit is ook van belang voor het uitbannen van honger en ondervoeding in ontwikkelingslanden. Deze inzet staat hoog op de agenda bij handelsmissies en ook het Nederlandse 'groen onderwijs' - wereldwijd toonaangevend - speelt hierin een belangrijke rol. Onlangs concludeerde ook het Hague Centre of Strategic Studies dat de export van Nederlandse kennis naast het versterken van de economische positie van de Nederlandse agrarische sector kan bijdragen aan het oplossen van mondiale problemen, zoals klimaatverandering en de invloed daarvan op het wereldwijde voedselsysteem. Toch is procentueel gezien de bijdrage nog sterk gericht op niveau 1 .

\section{Bedrijfsleven houden aan klimaatdoelen en SDG's}

Voor het bedrijfsleven is het van belang goed te bekijken hoe binnen de context van de SDG's gewerkt kan en moet worden. Het nationaal contactpunt voor de OESO-richtlijnen voor Multinationale Ondernemingen heeft eerder een bijeenkomst 'Eerlijk zaken doen met de SDG's' gehouden en zou in het vervolg een rol kunnen vervullen bij de naleving van het zogenaamde due diligence-principe. MVO-NL heeft hier ook een mogelijke rol. De MVO-checker maakt het voor bedrijven mogelijk zichzelf te toetsen op criteria rond duurzaamheid en arbeidsomstandigheden. De laatste jaren zijn er door diverse sectoren convenanten afgesloten om te voldoen aan internationaal maatschappelijk verantwoord ondernemen (IMVO). Het Initiatief Duurzame Handel (IDH) helpt het bedrijfsleven bij de verduurzaming. Ngo's houden druk op de ketel door naming en shaming en Eerlijke Banken- en Duurzame Handelslijstjes. In de mkb top 100 van 2017 staan meerdere bedrijven die actief zijn op de terreinen genoemd onder niveau 2. Bekeken kan worden of dergelijke initiatieven zich lenen voor een grotere markt. (https://www.duurzaambedrijfsleven.nl/voeding/24935/deze-7-agrifood-bedrijvenscoren-in-de-mkb-top-100)

Commerciële Nederlandse banken hebben een groeiende interesse in de nexus landbouw-waterklimaat-voedselzekerheid, maar blijven wel kijken naar risico's. Ontwikkelingsbank FMO is vaak aanjager van investeringen waar commerciële banken dit nog niet aandurven, maar die rol zou FMO sterker kunnen oppakken. Aandeelhouders in bedrijven kunnen druk zetten om in de bedrijfsvoering serieus werk te maken van de SDG's en de klimaatdoelen.

Een groep Nederlandse financiële instellingen heeft de regering en De Nederlandsche Bank (DNB) in december 2016 uitgenodigd om samen met hen de SDG's te ondersteunen. Ze hebben hiervoor het rapport Building Highways to SDG Investing opgesteld. Het is wereldwijd voor het eerst dat nationale pensioenfondsen, verzekeraars en banken samenkomen rondom een gezamenlijke SDG Investeringsagenda (SDGI). Verder draagt het samenwerkingsverband van acht multinationale ondernemingen, de Dutch Sustainable Growth Coalition (DSGC), bij aan de realisatie van de SDG's. Het bedrijfsleven ziet ook grote kansen in de ontwikkeling van een circulaire economie en in het tegengaan van voedselverspilling. Grote bedrijven en multinationals in Nederland hebben alle in 2017 de SDG's onderschreven https://www.vnoncw.nl/system/files force/global challenges dutch solutions.pdf en zullen nu ook 
boter bij de vis moeten/willen leveren. De vraag is welke garanties het Rijk kan en wil bieden waar het gaat om risicovolle investeringen en exporten en wat de inzet van het Rijk zal zijn om

investeringsverdragen aan te passen en belastingontwijking tegen te gaan. Op basis van de geuite ambities kun je stellen dat de ondertekenaars meteen voor niveau 2 willen gaan.

Het $\mathrm{mkb}$ is op allerlei manieren actief in de wereld. Veel ondernemers wagen de sprong. Aan de Keniaanse kust is een Nederlands bedrijf gevestigd (Equator Kenya Ltd.) dat op grote schaal chili pepers afneemt, met een duidelijk welvaartseffect op kleine boeren in de regio. In Ghana verzamelt Closing the Loop oude mobieltjes die anders weggegooid zouden worden. Verzamelaars verdienen hier een boterham mee en de recycling industrie krijgt een impuls. Het zijn maar twee voorbeelden. Het zou helpen een langere lijst aan te leggen.

\section{Netwerken}

MVO-NL beschikt over een enorm netwerk van duurzaam opererende bedrijven en financiële instellingen. Het heeft een programma Natuurlijk Kapitaal geformuleerd. Het ondersteunt agrofoodbedrijven hoe ze natuurlijke hulpbronnen duurzaam moeten benutten. De focusgebieden zijn: (i) duurzame winning/productie van inputs, o.a. nutriënten, chemicaliën, biotische grondstoffen voor voedselproductie; en (ii) duurzame teeltsystemen voor de productie van voedsel en andere biomassa; biodiversiteit en onder meer bodem, water, zaden. Het programma is gericht op opschaling van duurzaam omgaan met natuurlijk kapitaal (op basis van het Natural Capital Protocol), met als onderdelen in ieder geval een gezamenlijke ambitie en agenda; concrete, uitvoerbare impactprojecten; versterken samenwerking in ketens en gebieden; een randvoorwaarden-scheppend beleid, zoals duurzaam aanbesteden en/of grondstoffendiplomatie. Om dit te realiseren, worden vijftien tot twintig 'gamechangers' met een sterke drive om natuurlijk kapitaal op te schalen in de sector actief betrokken. De coalitie bestaat uit decision makers uit de hele voedselketen, inclusief toeleveranciers. Ook zijn vertegenwoordigers van de overheid, maatschappelijke organisaties en kennisinstellingen proactief betrokken. Alle partners hebben een ambassadeursrol en leveren een zichtbare bijdrage aan de doelen van het collectief. De initiërende kerngroep van het actieprogramma Agrifood bestaat uit Economische Zaken, IUCN, MVO (Ketenorganisatie Oliën en Vetten), Transitie Coalitie Voedsel, FNLI en MVO Nederland. Hier wordt een sterke beweging richting niveau 1 gegeven, met name aan de kant van de opschaling.

De topsector Agro\&Food meldt op de website dat het de activiteiten richt op drie lijnen waarbinnen men economische en maatschappelijke uitdagingen oppakt: Meer met minder; Hogere toegevoegde waarde; Internationaal leiderschap. Het gaat niet alleen om productie van duurzame en hoogwaardige voeding, maar ook om duurzame voedselketens waarin mens, dier en natuur centraal staan. De intentie zit ergens tussen niveau 1 en 2 in, maar verdient wel een verdere uitwerking.

Op de AgriFoodTech 2017 staan de volgende thema's centraal: machine construction \& automation, big data \& IT, smart \& vertical farming, testing \& quality, packaging, food design, social challenges as food waste, transparency and safe \& healthy food. Hier is te zien dat de onderwerpen zich bewegen zich tussen niveau 1 en 2.

Wageningen University \& Research heeft een enorm internationaal netwerk, via samenwerking in projecten, maar ook via studenten en distant learning-cursussen. Het model universiteit - hoger agrarisch onderwijs - agrarische opleidingscentra zou bijzonder goed kunnen werken in veel delen van de wereld. Versterking van kennissystemen is een exportproduct dat voor zowel opkomende als ontwikkelingslanden nog lang een uiterst zinvolle investering zal zijn. Het zit op niveau 1 omdat het al bestaat en opgeschaald kan/moet worden, maar qua thematiek zal het in toenemende mate niveau 2 en 3 centraal moeten gaan stellen. Er zijn nog talloze andere kennisinstellingen actief op de internationale markt die zich met agrofood, water en klimaat bezighouden. Ook is er een grote hoeveelheid ngo's actief. Vele zijn deelnemer aan de Strategische Partnerschappen die ressorteren onder Min BuZa. 


\section{Instrumenten}

Naast het DGGF en enkele andere fondsen en subsidies is het instrument SBIR waarschijnlijk het geschiktst om de beoogde transitie aan te jagen. Het kan ingezet worden voor innovaties waar bestaande Private Sector Development instrumenten niet toereikend zijn. Het gaat dan om precompetitieve activiteiten. Zowel het ontwikkelingsbeleid tijdens het kabinet-Rutte II als de brief 'Toekomst Bestendige Agrofood Export' geeft dit aan. Het is sterk op onderdelen van de keten gericht, verbindt bedrijven met producenten aan de base of pyramid via het model van cocreatie en het werkt met zogenaamde technology readiness levels.

FMO zou een prominente rol kunnen vervullen in het aanjagen van investeringen voor activiteiten waar een commerciële financier niet meteen aan wil, of voor partijen die nog geen trackrecord hebben om binnen te kunnen komen bij DGGF of andere grote fondsen. Het recente programma Making Africa Work dat jonge Nederlandse en Afrikaanse ondernemers aan elkaar koppelt, heeft veertig businessplannen opgeleverd waar nu financiering voor gevonden moet worden. Verder vormen remittances een mogelijk grote bron van duurzame investeringen en zijn er talloze private stichtingen en vrijwilligersorganisaties actief in ontwikkelingslanden. Zo voeren Nederlandse artsen en verpleegkundigen (deels van Marokkaanse origine) als vrijwilliger operaties uit in Marokko via de organisatie Santé pour tous. Hier zou meer beleid op gezet kunnen worden, zodat de initiatieven vanuit de overheid aansluiten op andere, misschien wat versnipperde en minder zichtbare, maar aanzienlijke financiële stromen. 


\section{$6 \quad$ Regio's}

\section{EU- en OECD-landen}

Op 8 december 2017 werd het JEFTA-verdrag getekend tussen de EU en Japan. Het NOS-bericht meldt: "Het creëert een handelszone waarvan 600 miljoen mensen deel uitmaken en waar ongeveer $30 \%$ van het wereldwijde bruto binnenlands product wordt omgezet. Naar verwachting gaan de Japanners uit Nederland vooral paprika's, bloemen en zuivelproducten importeren. Japan kan op zijn beurt goedkoper auto's naar Europese landen exporteren." Hierin klinkt nog geen urgentie om voorbij niveau 1 te komen. Die ambitie zou er wel kunnen zijn.

De sterke handelsrelaties met en exportpositie in EU- en OECD-landen moet het mogelijk maken sneller op te schuiven naar innovaties en technieken onder niveau 2. Het is zaak typisch Nederlandse sterktes te benutten, maar het integrale, climate smart en circulaire aspect daarbij centraal te stellen. De geografische kenmerken van Nederland helpen erg bij het vooroplopen in de sectoren landbouw en waterbeheer. Nederland is van plan met like-minded buren tempo te maken richting klimaatdoelen. Het afspreken van een $\mathrm{CO}_{2}$-prijs en het uit de markt nemen van ETS-rechten kunnen bijvoorbeeld een impuls vormen om op emissievrije technieken over te stappen. Het zou nuttig zijn het als Triple Win aangeduide gebied, waar food security, mitigatie en adaptatie bij elkaar komen, verder uit te werken.

\section{MENA-regio}

In de regio Marokko - Iran (MENA-regio) is waterbeschikbaarheid overal een (groot) probleem. In Libië is veel niet-duurzame grondwateronttrekking, in tegenstelling tot Marokko en Algerije. Veel Golfstaten voorzien in hun water via ontzilting, Iran en Egypte zijn middenmoters qua duurzaamheid. Hier liggen mogelijkheden voor de glastuinbouw en precisielandbouw, het bouwen van afvalwaterzuiveringsinstallaties en teelt op verzilte grond en van zeewier.

\section{Sub-Sahara Afrika en Zuid- en Zuidoost-Azië}

Misschien wel het meest veelzeggend is dat Afrika een piramidale bevolkingsopbouw heeft. Het gros van de mensen is jong. In Azië heeft de vergrijzing al enigszins ingezet. De werkende handen zijn straks Afrikaans.
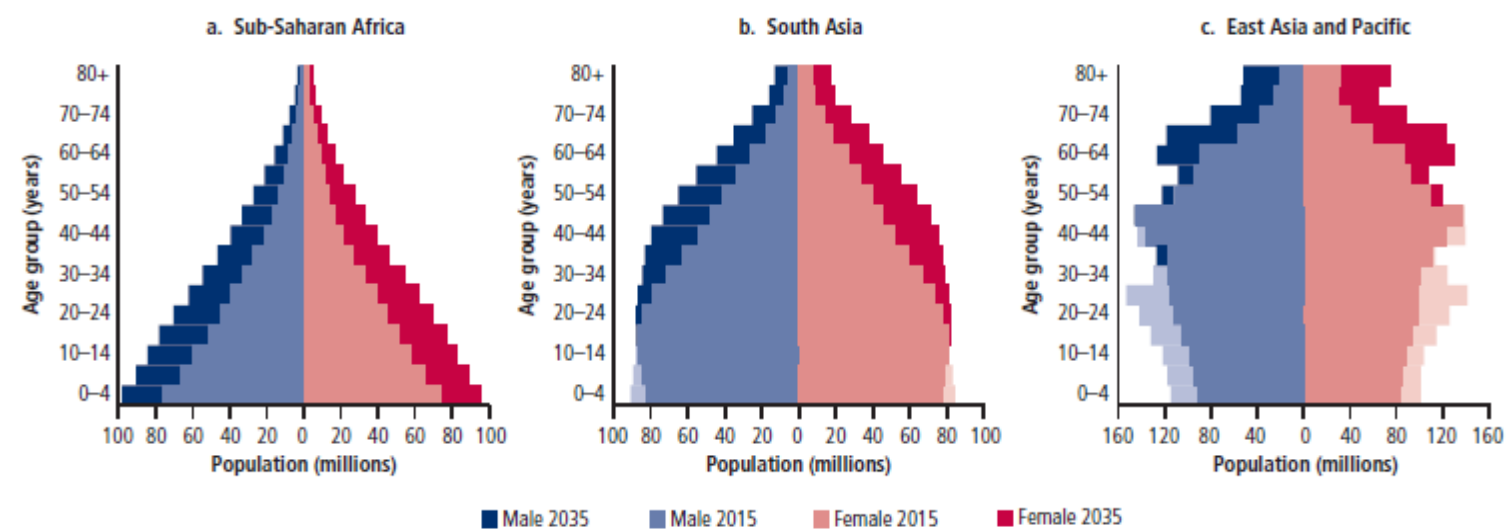

Source: Based on United Nations 2011

Het rapport The African Competitiveness Report (2017) geeft een goed cijfermatig overzicht voor de agrofoodsector per land.

Het Africa Development Forum beschrijft de kansen die de groeiende vraag naar voedsel biedt voor Afrika. De helft van de bevolking is jonger dan 25, elk jaar tot 2035 komen er een half miljoen jongeren van $15 \mathrm{bij}$. En dat terwijl de rest van de wereldbevolking begint te vergrijzen of al grijs is 
(Youth Employment in Sub-Saharan Africa (c) 2014 International Bank for Reconstruction and Development / The World Bank).

Ook ECDPM besteedt hier aandacht aan in de aanloop naar de in februari 2018 te houden conferentie 'Join-up with African Agripreneurs'. Enkele highlights zijn: (i) de focus ligt op de verbinding tussen platteland en stad, (ii) er is aandacht voor zowel macrobeleid (voedselhandel, voedselprijzen, finance, FDI, werkgelegenheid) als microbeleid (ketenefficiëntie, PHL, agrologistics, ICT, climate-smart agriculture), (iii) met de snelle groei van de Afrikaanse steden wordt het voedselzekerheidsprobleem extra urgent. Tegelijkertijd is de snelle groei van de urbane markten een kans voor Afrikaanse boeren/agripreneurs, mits ze in staat zijn om goede, verse producten te leveren als groente en fruit, zuivel en vlees, en (iv) Double Diamond. De Nederlandse vierhoek speelt in op deze uitdaging door middel van partnerships met Afrikaanse bedrijven, overheden, kennisinstellingen en maatschappelijke organisaties, zodat hun inzet voor het versterken van de linkages tussen platteland en stad en efficiënte voedselketens/-systemen duurzame effecten genereert.

Het Nederlandse bedrijfsleven is selectief en heeft lievelingslanden, waar andere landen enigszins verweesd achterblijven. Dit geldt ook voor overheden en bilaterale hulp. Dat heeft te maken met risicoperceptie door een bedrijf, dat wordt versterkt door de afwezigheid van een Nederlandse diplomatieke vertegenwoordiging en beschikbare en betrouwbare partners in het land. Een bedrijf dat als first mover deze stap zet, zou ondersteuning verdienen. Bij gebleken succes volgt de rest dan makkelijker.

Voor ontwikkelingslanden moet er naast het armoedebestrijdingsperspectief ook voldoende oog zijn voor businessontwikkeling. Een recente beleidsnota van de African Development Bank hamert daarop.

Africa Youth Rapport geeft aan dat landbouw in Afrika moet veranderen van een beroep dat je uitvoert omdat je niets anders kunt tot een dat barst van de dynamiek en kansrijkheid. Hiertoe zijn investeringen en beleidswijzigingen nodig, met special aandacht voor het binnenhalen van jongeren. Die kunnen dan (i) volledig boer worden, (ii) parttime boer worden gecombineerd met een bedrijf aan huis, of (iii) in loondienst. Om dit te bespoedigen, is het volgende nodig: betere financiële diensten en kredieten, beleid op gebied van landeigendom, zorgen voor adequate infrastructuur en mensen opleiden.

Een artikel in de Harvard Business Review laat zien dat er altijd één factor is die de efficiëntie van het totale food system beperkt. Soms is de verandering in het organisatieniveau doorslaggevend (coöperaties), soms een betere verhouding tussen verantwoordelijkheden van overheid en private sector. De combinatie van technologieontwikkeling, toenemende rendementen uit landbouw en enthousiasme genereren bij jongeren voor de agrosector is in opkomst in Afrika. Hoewel slechts $1 \%$ van commerciële leningen naar landbouw gaat, zien ondernemers steeds meer mogelijkheden om kleine boeren meer rendement te bieden. Er zijn meer mogelijkheden dankzij informatie van satellieten om realtime te monitoren. Er kan dan een betere oogstvoorspelling worden gedaan, die via sms-diensten is te verkrijgen. Gewasverzekering doet hier en daar zijn intrede. Nigeria heeft precisielandbouwbedrijfjes waar inputs, inclusief irrigatie, maximaal bijdragen aan outputs. Kenya heeft bedrijfjes die via big data van boeren een knowledge community maken. Toegang tot krediet verbetert, drip irrigation-systemen op zonne-energie worden geïnstalleerd. Bedrijfjes in Kenya en Kameroen richten zich op asymmetrie tussen producenten- en consumentenprijzen. In Ghana werken bedrijfjes met boeren die verder weg wonen via mobiele en webtechnologie. Sms-diensten maken overal opgang om marktinformatie te delen. Micro-entrepreneurs hebben hier het voordeel van de lokale kennis van een gefragmenteerde sector die zich moeilijk laat opschalen. Echter, wat al wel te merken is, is het enthousiasme bij jongeren om hiermee bezig te zijn. Ze zien ook in dat je alleen met mobiele apps geen voedsel verbouwt, maar deze technieken combineren met landbouw en voedselvoorziening is spannend. 
Transform smallholder agriculture

Policies to help smallholders move up

- Promote land rights and efficient land markets

- Enhance risk-management, mitigation, and adaptation strategies

- Support efficient, inclusive \& safe food value chains

- Develop young farmers

- Scale up productive cross-sector social safety nets

Shenggen fan. Way 2015 


\section{$7 \quad$ Relevante investeringsopties}

\section{Niveau 1}

1. Yield gaps sluiten (seed, water, soil, plant protection)

Vier technische factoren zijn cruciaal om de zogenaamde yield gaps te dichten. Gesteld dat de marktomstandigheden hoge productie aanmoedigen, dan helpt het wanneer plantmaterialen van goede kwaliteit, voldoende regenval/irrigatiewater, goede bodemvruchtbaarheid en/of toediening van meststoffen en beheersing van ziektes, plagen en onkruiden samengaan. Als een van deze schakels ontbreekt, rendeert vaak de investering in de andere schakels niet. Met name op het gebied van zaaizaad, pootgoed, kennis van fytosanitaire eisen en de efficiëntie van de tuinbouwsector is de Nederlandse positie ijzersterk en verenigd in Plantum NL en SeedNL, met o.a. een wereldspeler als Rijk Zwaan aan boord. Mkb-bedrijven lopen voorop in de ontwikkeling en export van klimaatvriendelijke stallen en kassen. Naast de teelt zelf gaat het dan ook om de slagvaardige organisatie van de productieketen en de korte lijnen tussen onderzoek, proefveld, teelt, lokale markt en export. Wat betreft water en bodemvruchtbaarheid ten behoeve van de landbouw heeft Nederland ook veel te bieden: precisie-irrigatie en bemesting zijn in een ver stadium van ontwikkeling dankzij het koppelen van spectrale kenmerken van bodem en plant met hun voedingstoestand. Producenten van organische meststoffen ontdekken nieuwe markten in Azië en Afrika. Daarnaast is er steeds meer ervaring met soilless cultures. Het Fertile Grounds Initiative kan partners verbinden. Voor gewasbescherming is verdere nadruk gewenst op integrated pest management om het gebruik van schadelijke chemicaliën verder terug te dringen. Diensten als Rikilt en Ctgb zouden zeer welkom zijn in veel delen van de wereld waar voedselveiligheid minder goed geregeld is dan in Nederland. Idealiter heeft elk gebied met een dominant gewas een optimaal systeem van integrated seed, water, nutrient and pest/disease management. In Ethiopië werd zo een effectieve combinatie van business ontwikkeling rond sesam (tweede exportgewas) en integrated seed systems gevonden. Opschalen van succesvolle technieken is van groot belang, maar niet iedere producent heeft de behoefte een optimale of maximale opbrengst te halen. Goed begrip van de productiebeslissingen is daarom noodzakelijk en daarmee inzicht in livelihood systems. In westerse landen varieert dit vaak tussen conventioneel en biologisch produceren, waarbij de ene boer winst maximaliseert en de andere 'het erbij doet'. In ontwikkelingslanden zijn veel modellen uitgeprobeerd om kennis over te dragen en technieken te delen met boeren en vervolgens uit te rollen (rapid rural appraisals, participatory technology development, farmer field schools). Thans wordt meer gewerkt volgens de theory of change, waarbij vanuit een gezamenlijk doel wordt bekeken welke wegen naar dat doel leiden en wat ervoor nodig is om er te komen. Veel Nederlandse ngo's hebben hier ervaring mee. Een meer techniek-gestuurde methode is de zoektocht naar best fits. Wanneer producenten een best fit hebben vastgesteld, kan via recommendation mapping met voorlichters in de regio opgeschaald worden zonder dat overal eerst een herhaling van de experimentele fase nodig is (CASCAPE, Ethiopië). Ook methodes waarbij het livelihood system centraal staat en een beroep wordt gedaan op de intrinsieke motivatie van de boer maken opgang, bijvoorbeeld met de PIP-methode in Burundi (https://www.youtube.com/watch?v=k175GPKAisY). Ook de 2SCALE-methode wordt gebruikt, de afkorting van 'Toward Sustainable Clusters in Agribusiness through Learning in Entrepreneurship'. Hier wordt beoogd public-private partnerships (PPP's) op te bouwen tussen kleine boeren, aangeduid als base of pyramid, en bedrijven die zowel korte als lange ketens bedienen en die tegelijk een inclusief karakter hebben.

Nederlandse inzet: het verbinden en op duurzame wijze optimaliseren van de onderwerpen zaaizaad/pootgoed/kasgroente, bodem/water en gewasbescherming voor een hoog productieniveau, aans/uitend op wensen en mogelijkheden van producenten, en de opschaling hiervan. Daarnaast de grote kennis op het terrein van integrated systems benutten, met zaaizaad, kunstmest e.d. als onderdeel van een bredere productiefilosofie. 


\section{Voedingskwaliteit verhogen}

Nederland heeft ook een grote naam op het terrein van levensmiddelentechnologie en voeding, zowel vanuit het onderzoek en onderwijs als het bedrijfsleven. De kwaliteit van voeding van kleine kinderen (de eerste 1000 dagen) lijkt cruciaal. Diverse invalshoeken zijn in het verleden gekozen, afhankelijk van de context: micronutriënten toevoegen aan meststoffen, voedingssupplementen ontwikkelen, landbouwproducten fortificeren (bijvoorbeeld Golden rice), meer diverse diëten samenstellen. Een zeer doeltreffende manier van kwaliteitsverbetering is het toevoegen van plantaardige eiwitten aan het dieet. Veel boonsoorten leveren dit en zijn ook nog in staat hun eigen stikstof uit de lucht te binden. Zij zijn daarmee klimaatvriendelijker dan gewassen die met fossiele energie tot stand gekomen kunstmest nodig hebben. Het door de Bill \& Melinda Gates gefinancierde programma N2Africa (http://www.n2africa.org/) springt eruit, met grote inbreng vanuit Wageningen University \& Research en de CGIAR. Nederland is ook goed in het leggen van de relatie tussen voeding en gezondheid, van jong kind tot oudere. Dat geldt zowel voor de Nederlandse kennisinstellingen, voor de grote voedingsconcerns en voor ngo's als Save the Children. In ontwikkelingslanden zijn de contacten met UNICEF van belang. Wie meer meegetrokken kunnen en moeten worden op dit onderwerp zijn fastfoodbedrijven.

Nederlandse inzet: versterken van de inzet op en de samenhang tussen de genoemde terreinen, meer interactie tussen agronomen, voedingskundigen en de medische wetenschap; extra inzet op goede voeding voor de eerste 1000 dagen en opschalen van succesvolle werkwijzen.

\section{Verliezen terugbrengen}

De voornaamste winst bij het terugbrengen van verliezen in het voorste deel van de keten zit in het verbeteren van het oogstproces, transport en opslag. Het middelste deel betreft de houdbaarheid van het product. Het achterste deel betreft verliezen bij de verkoop (over de datum, veilingoverschot, restjes op de markt), weggegooide overschotten uit restaurants, vliegtuigen en huishoudens en delen van plant en dier die als niet-eetbaar worden beschouwd. Op alle niveaus wordt inzet gepleegd om de verliezen terug te dringen, maar gezien de eerder genoemde percentages is hier een wereld te winnen. Voor het voorste en middelste deel moet de Nederlandse inspanning vooral in ontwikkelingslanden plaatsvinden, voor het laatste deel meer in OECD- en BRIICS-landen. Een probleem bij dit onderwerp kan zijn dat het belang voor het bedrijfsleven niet overal in de keten evident is en er wellicht aanvullend beleid nodig is om een forse opschaling te realiseren. Vooral in het voorste en middelste deel van de keten zijn Nederlandse bedrijven actief in het buitenland (bijvoorbeeld verbetering opslag van aardappelen, vervoer van tomaten, processing van fruit en zuivel).

Nederlandse inzet: overal in de keten waar verliezen zich voordoen, zijn ingrepen nodig. Sterkte van Nederlands mkb-bedrijfsleven en kennisinstellingen vooral in voorkomen van verliezen in het veld, tijdens transport en bij opslag en verbeteren houdbaarheid van versproducten. Terugdringen verliezen 'aan de dinertafel' vergt een andere inspanning: beïnvloeding van supermarkt, cateraar, restaurant als consument zelf.

\section{Capacity building, producentenorganisaties, gender, 'orgware'}

Waar wij trots zijn op ons OVO-drieluik, blijft het kennisniveau in ontwikkelingslanden nog achter. Het niveau van de landbouwvoorlichting blijft in veel ontwikkelingslanden achter, maar ook de aansluiting van de voorlichting op de markt. De voorlichter is te weinig een opschaler voor de boeren zelf (horizontaal) en een makelaar tussen de boer en het bedrijf (verticaal). Hetzelfde geldt voor de organisatiegraad van boerengemeenschappen. Outgrower gemeenschappen en andere coöperatieve werkvormen creëren schaal, macht en efficiëntie. Nederland kan hier actiever in zijn, bijvoorbeeld met partijen als Rabobank en Agriterra. Vrouwen moeten vaak hard werken, hebben een kennisachterstand en beperkt toegang tot financiële middelen, terwijl zij voor een belangrijk deel van de voedselproductie zorgen. Dit zou meer aandacht voor de rol/positie van vrouwen bij het versterken van voedselzekerheid rechtvaardigen. Vrouwen investeren meer van hun inkomen in voedselzekerheid en gezondheid van hun familie dan mannen. Ze zijn verder verantwoordelijk voor $60-80 \%$ van de voedselproductie in ontwikkelingslanden. In Azië en Afrika werken ze 12-13 uur per week meer dan mannen. Training moet meer gericht zijn op een livelihood pakket dan puur farming (boer heeft meer inkomstenbronnen, focus van ons te veel op landbouw zelf) en op recommendation mapping. In BRIICS-landen is veel behoefte aan een praktische landbouwopleiding op mbo-/hbo-niveau. Het Nederlandse model universiteit - hbo - aoc kan zeer goed als voorbeeld dienen voor andere delen van 
de wereld. In veel BRIICS- en ontwikkelingslanden ligt het accent zwaar op universitaire scholing en genieten de hbo-/mbo-niveaus te weinig aanzien. Veel afgestudeerden blijven na het behalen van hun titel hangen in onderzoek dat niet tot snelle ontwikkeling van de landbouwsector leidt. Studenten en voorlichters worden vaak opgeleid in hardware (dichten van yield gaps) en software (participatory rural appraisals), maar wat vaak mist, is de 'orgware' (vrij naar Cees Leeuwis, WUR). In die middencategorie bevinden zich de onderwerpen landrechten, prijszekerheid, marktregulering, arbeidsmarkt, collectieve actie en organisatie, dienstverlening en wetgeving, certificering en vergunningen. Dit zijn cruciale onderwerpen om tot een opschaling te komen. Het past ook bij de opmerking van de IFPRI directeur dat small niet altijd beautiful is. Er is shifting conversation nodig.

Nederland kan hier op alle fronten bijdragen, met formele en informele opleidingen en trainingen. Nuffic speelt hierin een grote rol richting ontwikkelingslanden, het 'groene onderwijs' is in zijn volle breedte ook een exporteerbaar model voor BRIICS-landen. De aandacht voor 'orgware' in het opschalen van voedselzekerheid gaat eigenlijk boven niveau 1 uit, maar verdient de volle aandacht in curricula in de klas en op het kantoor van de voorlichter. De grote rol van vrouwen bij het realiseren van voedselzekerheid is evident en wordt - gezien teksten in Afrikaanse beleidsdocumenten - ook steeds beter onderkend. Hierop kan worden doorgepakt doordat Nederlandse ngo's hier veel ervaring mee hebben.

\section{Niveau 2}

\section{Climate smart produceren}

Er zal een sterke focus moeten komen te liggen op innovaties die concreet bijdragen aan het reduceren van $\mathrm{CO}_{2}$-uitstoot en andere broeikasgassen (mitigatie) en aan het aanpassen van landbouw-, water- en voedselsystemen aan veranderend klimaat (adaptatie). Mitigatie komt feitelijk neer op alle handelingen die de noodzaak tot het gebruik van fossiele brandstoffen en het in gebruik nemen van nieuw koolstofrijk areaal verkleinen. Adaptatie is het omgaan met de klimaatverandering zelf: aanpassen aan droogte of verzilting, vermijden or verkleinen van het schaderisico. Dit moet tegelijkertijd het duurzaam gebruik van natuurlijke hulpbronnen ten goede komen en het efficiënt inzetten van inputs in de landbouw (hoge opbrengst per kunstmestkorrel, per druppel water, per kilo bestrijdingsmiddel), waardoor ander areaal niet hoeft te worden geëxploiteerd. De complete voedselketen moet hier in feite op gecontroleerd worden. Overal zijn aangrijpingspunten, van de brandstof van het landbouwwerktuig tot het fornuis van de consument en de inhoud van de pannen.

\section{Voorbeeld 1: Planten veredelen op abiotische kenmerken}

$\mathrm{Er}$ is een enorme behoefte aan gewasvariëteiten die beter tegen droogte en zout kunnen en die beter gedijen op bodems met lage vruchtbaarheid, door aanpassing van de fysiologie van de plant en/of door het ontwikkelen van een breder of dieper wortelstelsel. De zoektocht naar de genen die deze eigenschappen vertegenwoordigen, is van groot belang. Zaaizaadbedrijven en handelaren hebben Plantum NL als venster naar de buitenwereld (https://www.youtube.com/watch?v=tkkI3Ki8sHc). Via SeedNL wordt dit verder verbreed met andere spelers. Naast de invalshoek 'veredeling' zijn ook de invalshoek 'fysiologie' en 'waterefficiëntie' van belang (more crop per drop) en in handen bij Wageningen Plant Research. Vooral in landen in de MENA-regio, droge streken en in verziltende delta's is dit type kennis en ontwikkeling cruciaal om bij te dragen aan efficiënt gebruik van water en realisatie van voedselzekerheid.

Voorbeeld 2: Blue growth

Er ontstaat een steeds beter beeld van de mogelijkheden om zeewier en algen te benutten en de vervanging van vlees door vis, o.a. via aquacultuur en in het bijzonder de innovatie 'aquaponics', waarbij visteelt onderdeel wordt van een circulair systeem met groenteteelt. In Nederland zijn mkbbedrijven en start-ups hiermee bezig, maar ook kennisinstellingen (o.a. Wageningen Animal Research). Het is in Nederland niet onmiddellijk rendabel, maar met enige schaal van betekenis kan dat wellicht veranderen, zeker in het buitenland. In de natte tropen wordt soms rijst, vis en Azolla (een eencellige groenbemester) gecombineerd. (In het frans: Azollarizipisciculture. Dit is op de tekentafel een prachtig duurzaam, climate smart-systeem, maar nooit heel groot geworden.) 
Voorbeeld 3: Precisielandbouw en minimale grondbewerking

Precisielandbouw betekent dat bodem en plant op basis van hun spectrale kenmerken precies krijgen waar ze op een bepaalde tijd in het groeiseizoen behoefte aan hebben. Met deze innovatie wordt toediening van (irrigatie)water, kunstmest en gewasbeschermingsmiddel zowel milieu- en klimaatvriendelijk als kosteneffectief. In Nederland zijn kennisinstellingen en mkb-bedrijven zeer actief op dit terrein. Ook minimale grondbewerking (conservation tillage) is climate smart en tegelijk kosteneffectief. Soms is de beste manier om koolstof op te slaan op land namelijk om er zo veel mogelijk van af te blijven. Tropische bossen en savannes moeten niet alleen gespaard blijven vanwege hun biodiversiteit, maar ook omdat ze bovengronds en ondergronds grote voorraden koolstof herbergen. Met name veengebieden zijn zeer koolstofrijk, maar raken alles kwijt na blootstelling aan zon en vuur (ZuidoostAzië, palmolie). Dit geldt trouwens ook voor de Nederlandse veenweidegebieden, waar heel veel $\mathrm{CO} 2$ de lucht in verdwijnt door het steeds verder verlagen van de grondwaterstand. Ook de steppengronden in Oost-Europa, Rusland en Kazachstan zijn zeer koolstofrijk en hebben veel te verliezen. In veel gebieden in de wereld, bijvoorbeeld de Braziliaanse sojagebieden, wordt daarom in toenemende mate minimale grondbewerking toegepast. Zo wordt de natuurlijke organische stoflaag in de bovengrond zo min mogelijk blootgesteld aan afbraak. Het betreft nog een innovatie waarvan het werkelijke voordeel nog goed moet worden vastgesteld. Kennisinstellingen, ook internationaal (CGIAR) en mkb-bedrijven actief op het ontwikkelen van geschikte landbouwwerktuigen, zijn aan zet op dit onderwerp.

Nederlandse inzet: de hele keten dient nageplozen te worden op mogelijkheden voor mitigatie en adaptatie. Waar de drie elkaar raken (Triple Win), zit de meeste toegevoegde waarde richting het halen van klimaatdoelen. In ontwikkelingslanden staat adaptatie voorop en is mitigatie vooral gekoppeld aan efficiënt gebruik van land en inputs. Een systeem analoog aan de Milieu Effect Rapportage zou nuttig kunnen zijn om voortgang te monitoren.

\section{Efficiënte ketens opzetten}

Welke (sectoren in) exportlanden hebben ketentransformaties nodig of zijn daarmee bezig? Het kunnen korte en lange ketens zijn, en betrekking hebben op input supply chains zoals kunstmest en zaaizaad, of juist op producten voor de export. In ontwikkelingslanden is een aanpak volgens een waardeketen nog vrij nieuw, of nog verdeeld in segmenten. Voorbeeld: alle mango's worden tegelijk rijp en we starten een bedrijf dat mangosappen maakt in flesjes of pakjes. Maar daarna is ook nog een markt nodig. En de boeren moeten wel voor langere tijd mango's leveren. Zijn de bomen niet te oud? Is er geen risico op prijsdaling? Waar zit de afnemer? De meeste innovaties die in aanmerking komen voor het SBIRinstrument zijn keten-gerelateerd en gekoppeld aan de terreinen inputs (zaaizaad, meststoffen, gewasbescherming), primaire productie (spectrale bodemanalyse, apps voor ziekteherkenning, aquaponics), post-harvest (solar-powered aardappel opslag), waarde toevoegen (drying en processing faciliteiten), versterken van de keten (product apps, track and trace in supply systeem, agrodealer information system), toegang tot marktinformatie, financiering (mobiel bankieren) en verzekering. Op al deze onderdelen zijn Nederlandse kennisinstellingen, grote en mkb-bedrijven en ngo's actief. Het Agrofoodcluster (http://agrofoodcluster.com/) is een landelijk opererend cluster, opgezet en gefinancierd door bedrijven en organisaties uit de open teelt. Deze partners vertegenwoordigen een jaaromzet van circa 2 miljard euro. De drie pijlers van het Agrofoodcluster zijn: verspreiden van kennis, het aanjagen van innovatie en het stimuleren van business in de open teelt. De keuze voor een innovatietraject is afhankelijk van het type keten waar de producenten onderdeel van uitmaken of zouden kunnen uitmaken als de keten efficiënt en winstgevend functioneert. Dat kan het geval zijn wanneer bijvoorbeeld de fysieke en psychologische afstand tot een markt (de stad) verkleind wordt.

Nederlandse inzet: We hebben hier een forse meerwaarde, omdat ketens in Nederland zeer goed zijn georganiseerd. Productie, verwerking, export en kennis zitten dicht bij elkaar en weten elkaar te vinden. Multinationale ondernemingen als Unilever zijn goed in lange en verticale 'ketens', waarbij productie, toelevering, verwerking en retail aan elkaar geschakeld zijn. Het IDH werkt met FMO en bedrijven om in ontwikkelingslanden de brug te slaan tussen producent en bedrijf/markt.

Risicoperceptie is hierbij een obstakel. De noodzaak is in Afrika groot om rurale productie en urbane consumptie aan elkaar te knopen. Daar zijn consortia voor nodig met beta-gammakennis, maar ook modellen als cocreatie waar bedrijven en producenten die zich aan de base of pyramid bevinden elkaar vinden. Het bedrijf verplicht zich dan ook om armoede te bestrijden door living wages te betalen en banen te creëren. Het kan en moet jongeren binden aan de agrofoodsector, maar dan niet meer puur als boer, maar als schakel in de keten. 


\section{Circulair produceren}

Dit belangrijke domein gaat over het sluiten van kringlopen en het herbenutten van reststromen. De Nederlandse afvalsector en de waterschappen lopen al voorop in Europa met hergebruik van materialen en energieterugwinning uit de centrales en de rioolwaterzuivering. Bij het terugwinnen van fosfaat uit reststromen zijn meerdere Nederlandse ketenpartijen betrokken via het nutriëntenplatform (https://www.nutrientplatform.org/). Dit platform is vervolgens weer leidend in de EU om de Kunstmestrichtlijn aangepast te krijgen, zodat het teruggewonnen materiaal struviet niet meer als afval wordt geclassificeerd. Hier ligt een groot internationaal veld braak, waar ook gft-afval, gewasresten, doordraaiproducten, productieafval, etensresten, oud frituurvet, dierlijke mest en overde-datum-producten een nieuw leven tegemoet gaan. In ontwikkelingslanden gaat het in eerste instantie om het versneld hergebruiken van organisch afval, maar ook bijvoorbeeld het omzetten van zeewier tot diervoeder (een business proposal in Making Africa Work). Het kan een dubbele winst opleveren, omdat iets wat als een nuisance wordt opgevat of een milieurisico herbergt, niet alleen wordt opgelost, maar ook nog nieuwe waarde krijgt. Compostering, vergisting of verwerking tot diervoeder geeft nieuwe waarde aan afval. Het vermarkten van deze producten biedt veel mogelijkheden, over korte afstanden (van mesterij naar groentetuin) en lange afstanden (export van mestkorrels). Traditioneel wordt in ontwikkelingslanden nog een immense hoeveelheid (deels organisch) afval gestort in en rond steden. Dit afval vervuilt grond- en drinkwater. Innovatieve mkbbedrijven en start-ups zijn het actiefst in dit domein, dat varieert van compostering ter plekke tot het verhandelen van organische mest tussen Nederland en een bestemming in een ontwikkelingsland. Azië is hiermee verder dan Afrika. Er worden uiteraard ook veel machines en andere goederen gebruikt in de agrofoodsector die niet te composteren zijn, maar wel te recyclen. In algemene zin moet gewerkt worden aan een verandering van de mindset: van een lineaire naar een circulaire maatschappij.

Een niet onbelangrijke bron van eigenbelang wordt beschreven door HCSS en Wageningen Economic Research. Houdt Nederland in de toekomst voldoende toegang tot belangrijke grondstoffen? Fosfor bijvoorbeeld is een schaars wordende grondstof waarvan Marokko en China samen het leeuwendeel produceren. Maar ook stikstof, kalium, thee, koffie, allerlei soorten oliën, fruit, groente en voedergewassen zoals sojaschroot, worden geïmporteerd. Een zekere mate van zelfvoorziening is daarmee niet autarkisch, maar wellicht strategisch. Maar vooral vormt deze overweging een aanleiding zo snel mogelijk op een circulaire maatschappij over te stappen.

Nederlandse inzet: De hoofdopdracht is het sluiten van kringlopen. Afvalinzameling en het terugwinnen van bruikbare materialen uit reststromen is een grote markt. Succesvolle mkb-bedrijven zijn in Afrika gestart met het verzamelen en hergebruiken van mobiele telefoons (bijvoorbeeld Closing the Loop). Gered Gereedschap zamelt niet alleen in Nederland materialen in, het leidt ook Afrikanen op tot vaklieden. Bedrijven actief in het Nutriëntenplatform hebben relevante expertise voor OECD- en BRIICS-landen (afvalsector, diervoedersector, Royal Cosun en Avebe bijvoorbeeld op hergebruik reststromen uit suiker en aardappelen). De combinatie waterschappen - drinkwaterbedrijven is ook een sterke troef bij het onderwerp (riool)waterzuivering. Het initiatief Making Africa Work leverde meerdere businessplannen op om van afval grondstof te maken, o.a. rond plastic en zeewier. Better Future Factory werd de winnaar. Binnen o.a. het Fertile Grounds Initiative wordt verkend welke organische voorraden vanuit steden kunnen worden overgebracht naar het peri-urbane gebied waar tuinbouw plaatsvindt. Nederland moet in zijn handelsrelaties rond producten die mogelijk schaars worden, zorgen dat het op meerdere leveranciers kan terugvallen en innovatieve partnerships aangaan met landen waar deze producten vandaan komen. 


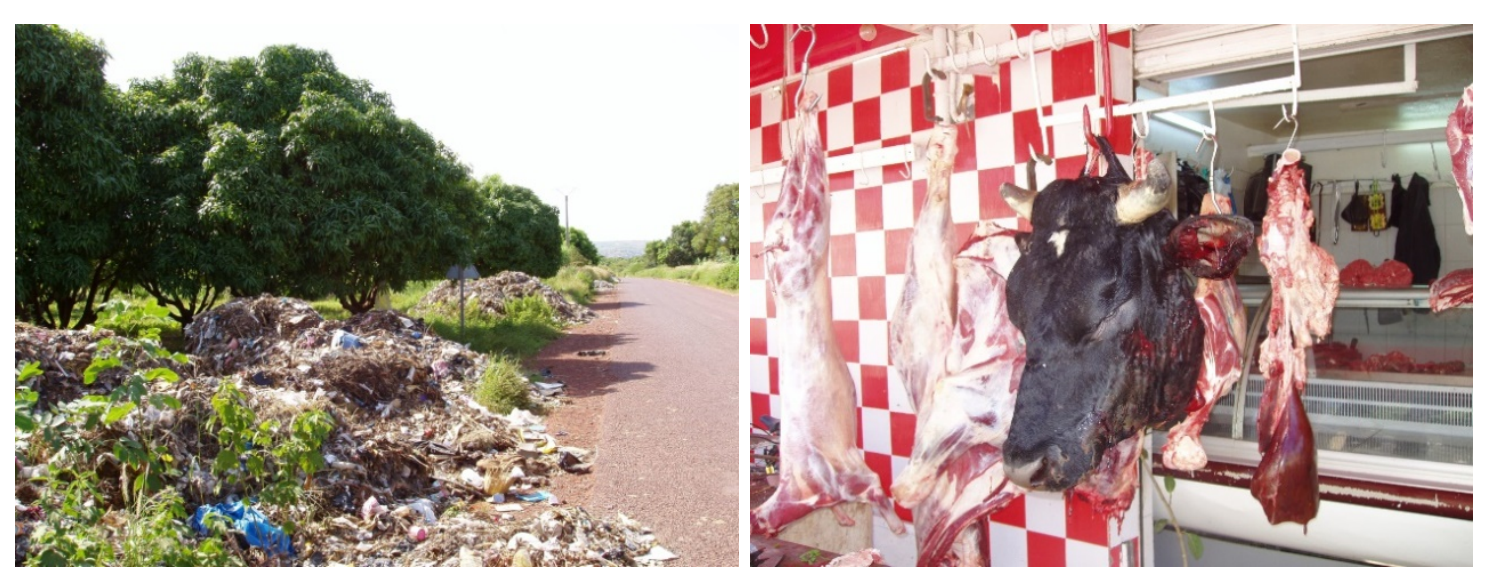

\section{Integratie op systeemniveau}

We zijn als Nederland goed in integrale benaderingen, waarbij gedacht wordt in systemen en processen en de uitkomsten van activiteiten en interventies op het systeem. Dit is wellicht het gevolg van de aandacht voor bèta-gamma-integratie in opleidingscurricula. Drie soorten systeemdenken zijn relevant en ook inzetbaar in het internationale agrofood veld: (i) systemen rond de plantaardige of dierlijke productie, (ii) systemen die gekoppeld zijn aan ruimte (perceel-bedrijf-landschapstroomgebied-wereld) en tijd (morgen-groeiseizoen-2030-volgende IJstijd) en (iii) scenariostudies die randvoorwaarden opleggen aan systemen. Het Planbureau voor de Leefomgeving heeft veel ervaring met het laatste.

Zoals eerder aangegeven, hebben we naast het genereren van goed eerste-generatie plantmateriaal ook goed zicht op seed systems als onderdeel van een breder landbouw- en voedselsysteem. Hetzelfde geldt voor het naast elkaar beheren van in situ en ex situ agrobiodiversiteit (o.a. WUR Centrum voor Genetische Bronnen), het succesvol inpassen van innovaties zoals zero grazing in bestaande bedrijfssystemen in Afrikaanse hooglanden, inclusief bijbehorende veterinaire diensten en voedergewassen. Daarnaast weten we hoe we moeten opschalen van een bedrijf naar het niveau 'landschap' of 'stroomgebied' of andere relevante schaalniveaus en welke factoren op welk niveau het opschaalsucces bepalen. IDH werkt met een landschapsprogramma waarbij de teelt van een gewas als cacao in West-Afrika gekoppeld is aan randvoorwaarden op het terrein van verdere boskap. In Brazilië werkt IDH aan de intensivering van de dierhouderij in Mato Grosso, zodat de helft van de huidige 300 miljoen hectare waar 1 koe per hectare rondloopt, kan worden herbebost, zonder productieverlies. De overheid werkt hieraan mee. Scenariostudies bieden doorkijkjes over de ontwikkeling van gebieden onder verschillende (klimaat- of duurzaamheids-)doelen en randvoorwaarden. Hier worden agrotechnische en sociaaleconomische indicatoren met elkaar verbonden.

Nederlandse inzet: veel kennispartijen en ngo's zijn actief op de bedrijfs- en landschappelijke systeemniveaus. Het lijkt niettemin zinvol een overzicht te maken van relevante systeeminnovaties en geïntegreerde concepten die klimaat- en duurzaamheidsdoelen dichterbij brengen en de systeem-en scenariobenadering meer internationaal uit te venten. Op het laatste terrein lijkt buiten Nederland met name ingezet te worden op deelname aan regionale en mondiale studies door de EU en de VN.

\section{Steden bevoorraden en voeden}

In veel West-Afrikaanse landen is het goedkoper voor de kuststeden om voedsel te importeren dan het uit eigen land aan te voeren. Hier kan veel in verbeteren. Voor megasteden is een plan nodig om in de toekomst voldoende voedsel naar binnen te krijgen en ook om de reststromen te herbenutten. Nederland heeft metropolitan solutions in de aanbieding (http://www.amsinstitute.org/institute/home/; (http://agendastad.nl/city-deals) die ongetwijfeld weerklank vinden in andere grote steden. Hier hoort ook vertical farming bij (http://www.verticalfarm.nl/). Gesloten systemen in en rond steden (afsluiten gebouwen, ledlicht) kunnen de druk van ziektes en plagen verminderen en duurzaam en klimaatneutraal gemaakt worden. Een deel van de voedselvoorziening die nodig is in de groeiende steden kan hierdoor dichtbij de consument plaatsvinden. De keuze voor o.a. stadslandbouw en circulariteit op de Floriade van Almere in 2022 lijken goed gekozen. In de MENA-regio vinden met Nederlandse inbreng ook verbeteringen plaats op het terrein van koude 
opslag, betere oogsttechnieken, betere logistiek en de ontwikkeling van metropolitane food clusters. De veranderende vraag in low and middle income countries speelt hier een grote rol. De opkomende middenklasse groeit snel in Afrika, is in Azië al aanwezig, verandert van dieet waarbij de openluchtmarkt wordt ingeruild voor supermarkt en restaurant. Fastfood ketens groeien als kool en domineren de malls aan de rand van Nairobi en Manila. De grote uitdaging in landen met een aanzienlijke urbanisatie op komst is om base of pyramid boeren in het rurale gebied te koppelen aan de consument in de stad. Dit komt maar niet op gang.

Nederlandse inzet: Multinationale bedrijven en grote mkb-bedrijven moeten hier de stap zetten, met FMO en andere financiële instellingen, om meer risico te accepteren. Dat zal ook aan aandeelhouders moeten worden voorgelegd. Dit is echt noodzakelijk om de echte opschaling tot stand te brengen. Productie opschalen (niveau 1) kan, maar een sterke en efficiënte relatie met de groeimarkt in de stad is onmisbaar. Economen en planologen moeten kijken naar de financiële en fysieke ontwikkeling van steden. Er zijn partijen als Agriterra nodig om producenten te helpen met het opzetten van coöperaties en outgrower schemes. Gremia van burgemeesters wereldwijd kunnen hier ook een rol spelen. Stedenbanden zouden effectiever worden wanneer specifiek op voedselzekerheid ingezet zou worden, met uitgewerkte klimaat- en duurzaamheidsdoelen. Hier ligt misschien een rol voor VNG.

\section{Normering, kwaliteitscontrole, wettelijke barrières op orde brengen}

Verschillen in wet- en regelgeving tussen landen en werelddelen kan effectieve samenwerking en een succesvolle overstap naar duurzame food systems ernstig bemoeilijken. Vaak aan de orde zijn kwesties rond de toelating van gewasbeschermingsmiddelen en gentech producten of de gehanteerde drempelwaarden van toxische stoffen (aflatoxines in pinda bijvoorbeeld). De publieke opinie speelt hierbij ook een rol, met zelfs verschil in opvatting tussen bijvoorbeeld VN- en EU-instellingen over het al dan niet kankerverwekkend zijn van glyfosaat. Een melkschandaal in China leidde tot een run op Nederlandse melkpoeder, waarmee aangegeven is hoe sterk de middenklasse in China al reageert op een nationale voedselveiligheidskwestie. Kenia heeft een controleorgaan voor zaaizaadkwaliteit, Ethiopië niet. De verschillen zijn merkbaar in het veld.

Nederland kan een grote rol spelen in het opbouwen en versterken van capaciteit op deze terreinen. Veel BRIICS- en ontwikkelingslanden hebben behoefte aan organisaties met deskundigheid op het gebied van levensmiddelentechnologie en toxicologie, die over toelating en vergunningen kunnen beslissen, zoals NVWA, COKZ, RIKILT, Ctgb, NAK Tuinbouw etc.

\section{Koppelen van functies in het landelijk gebied}

Landbouw concurreert met ander landgebruik, maar als je goed kijkt heeft niet elke vierkante meter maar één bestemming. Al twintig jaar geleden bracht Nederland het concept van 'multifunctioneel landgebruik' binnen bij FAO, maar het is nog niet grootschalig uitgerold. Wellicht dat onze bevolkingsdichtheid de noodzaak groter maakt. Er zijn niettemin grote mogelijkheden om deze kennis breder in te zetten en klimaat- en duurzaamheidswinst te halen. Intensieve landbouw vlak naast belangrijke natuurgebieden zoals die in Natura 2000 blijkt bijvoorbeeld problematisch vanwege stikstofdepositie. Daarom worstelt Nederland zelf ook met een route die landbouw en natuur samen tot een agro-ecosysteem maakt. Voorlopig is daar de Programmatische Aanpak Stikstof voor bedacht, een model dat aan verkeer, industrie en landbouw een gelimiteerde hoeveelheid stikstof toekent, waarbij de instandhoudingsdoelen van de te beschermen ecosystemen niet in gevaar komen. Dit is innovatief, al moet nog blijken of het ook doet wat het belooft. Andere nuttige combinaties van functies zijn de aanleg van wegen, die tegelijkertijd als waterbarrière dienen en nuttig gebruikt kunnen worden voor de landbouw en huishoudelijk gebruik, en het blokkeren en tegenhouden van water dat dreigt weg te stromen na hevige regenval, met name in gebieden waar die regenval over het hele jaar gemeten schaars is. In MENA-gebieden wordt in dit soort gebieden spate irrigation toegepast, maar het beheer van dit water kan nog sterk verbeteren. Kennisinstellingen en mkbbedrijven (http://metameta.nl/) zijn actief op dit terrein. Binnen het Deltaprogramma is ervaring op het bijeenbrengen van waterveiligheidsbeleid en de ontwikkeling van natuur en recreatie. Dit kan in de toekomst ook gaan gelden voor zonneweiden met daaronder energiegewassen of kleinvee. Er zijn ook goede mogelijkheden om peri-urbane landbouw meer in dienst te stellen van de stad en reststromen te hergebruiken. Verbindingen leggen tussen stad en de natuur- en recreatiefunctie van het ommeland is ook een Nederlandse specialiteit. Tegenwoordig duiden we dit vaak aan als 'meekoppelkansen'. 
Nederlandse inzet: er is een innovatieve zoektocht nodig naar een optimaal naast elkaar bestaan van landbouw en natuur, zonder de illusie te hebben dat er alleen win-winsituaties zijn. Dit is ook van belang voor het nieuwe GLB vanaf 2020. De grote ervaring op het gebied van ruimtelijke ordening moet ingezet worden om functies van het land te verbinden, waardoor de sociale, economische en ecologische waarde zo goed mogelijk en in samenhang wordt benut. In veel steden wereldwijd en hun ommelanden is hier behoefte aan.

\section{Niveau 3}

In de Wageningen University \& Research publicatie Food Transitions 2030 staan acht groepen oplossingen centraal, die alle moeten bijdragen aan duurzaamheids- en klimaatdoelen, die circulair, gezond, innovatief en inclusief moeten zijn. Deze groepen zijn:

- slimme veredeling van plant en dier (o.a. verhogen efficiëntie fotosynthese)

- next level landbouw (digitalisering, robotisering, precisielandbouw, ketenintegratie)

- blauwe groei (algen, wieren, mariene biotechnologie)

- proteïnetransities (van dier naar plant)

- innovaties in voedselproductie en -verwerking

- digitalisering van de maatschappij

- voedingspatronen

- voeding en gezondheid

Deze onderwerpen maken deel uit van de food systems die in 2030 gemeengoed zouden moeten zijn. Zover zijn we nog niet, maar het zou goed zijn de onderwerpen te koppelen aan de figuur uit Van Berkum et al. (2017) en vervolgens te kijken naar de toepassing van de onderwerpen in verschillende delen van de wereld.

Een andere manier om via niveau 3 te kijken, is via 'sector development'. De notitie-in-wording Agricultural Sector Development - Guidelines for Aid \& Trade support in Dutch Private Sector Development (PSD)-partner countries biedt hiertoe ingangen, waarbij de hele keten wordt langsgelopen. Afgesloten wordt met een aantal succesfactoren die bij de food systems van de toekomst horen:

- de businesscase is leidend en niet een needs assessment van beneficiaries; hoe duidelijker de winstgevendheid van een investering in de agrofoodsector, hoe makkelijker de activiteit duurzaam en inclusief gemaakt kan worden;

- er moet een scala aan mogelijkheden zijn om bedrijfsrisico's te verkleinen; alleen dan kan de producent leveren en zich verplichten aan zijn rol in de keten;

- hoge transactiekosten bij producenten moeten vermeden worden door horizontale integratie (coöperatieve organisaties) of door te werken met grotere bedrijven, aangezien die anders met schaal en marges omgaan.

Ook IFPRI bepleit de ontwikkeling van nieuwe food systems met de volgende kenmerken:

\section{Rethinking the global food system}

\begin{tabular}{ll}
$\begin{array}{l}\text { OLD } \\
\text { Food security is mainly a supply } \\
\text { problem }\end{array}$ & $\begin{array}{l}\text { Accessibility issues are major } \\
\text { problems }\end{array}$ \\
$\begin{array}{l}\text { Sustainable intensification with } \\
\text { more output }\end{array}$ & $\begin{array}{l}\text { Sustainable intensification with a } \\
\text { focus on nutrition }\end{array}$ \\
$\begin{array}{l}\text { Small(holder) is always beautiful } \\
\text { Context specificity matters }\end{array}$ \\
$\begin{array}{l}\text { Self-sufficiency is beneficial } \\
\begin{array}{l}\text { Food losses and waste do not } \\
\text { really matter }\end{array}\end{array}$ \\
$\begin{array}{l}\text { Open, transparent, and fair global } \\
\text { trade provides more gains }\end{array}$ \\
$\begin{array}{l}\text { Food losses and waste matter } \\
\text { greatly }\end{array}$ \\
Nobal governance dominated by & $\begin{array}{l}\text { Safety of food systems is } \\
\text { increasingly at risk }\end{array}$ \\
No attention to gender & $\begin{array}{l}\text { Emerging economies now play a } \\
\text { bigger role }\end{array}$ \\
Shenggen Fan, May 2015 & Gender has key role in agriculture \\
\hline
\end{tabular}


Fresco et al. (2017) zeggen het als volgt: Het dominante food system is agro-industrieel, gedomineerd door een aantal multinationals via verticale integratie. Het zijn complexe, lange voorraadketens, t/m processed foods gestuurd via supermarkten, restaurants en cateringbedrijven. Daartegenover staat family farming met korte ketens, gestuurd via lokale winkels en openluchtmarkten. Vooral Azië zit er tussenin, en dit is ook de grootste groep.

Volgens het World Economic Forum 2017 moeten toekomstbestendige food systems het volgende zijn: inclusief, duurzaam, efficiënt en voedzaam. Kritieke factoren zijn: urbanisatie en megacities (druk op land; landrechten); de noodzaak om de agrofoodsector naar een hoger plan te tillen (investeringen, werkgelegenheid, meer toegevoegde waarde door processing, handel, verpakking, diversificatie); management van toegang, distributie en prijs op scheidsvlak ruraal-urbaan: prijsverschillen dempen, verzekeringen tegen verliezen, regionale handel, weather forecasting via satellieten.

De vraag is natuurlijk ook of op een bepaald moment prijsregulering zinvol is, of het aanleggen van grotere buffervoorraden. Dergelijke beleidskeuzes zijn zeer bepalend voor het food system. Op hoofdvoedsel zoals rijst, maïs en tarwe wordt prijsregulering vaak toegepast en de EU kent interventieprijzen, maar veel vers- en dierlijke producten kennen dit niet. Dit vergt een voortgaande discussie.

ECDPM benadrukt dat het voedselsysteem wereldwijd getransformeerd dient te worden waarbij aandacht voor losse onderdelen van ketens niet meer genoeg zal zijn. Daarmee zetten ECDPM en de beoogde conferentie sterk in op niveau 3. Het benadrukt ook de politieke dimensie, omdat deze transformatie alleen tot stand komt via politieke prioritering met oog voor de effecten van nietduurzaam landgebruik, scheve handelsbalansen en ongelijkheid.

Uiteindelijk is er misschien wel een Parijs II nodig, maar dan voor het sluiten van een wereldwijd Voedselakkoord. 


\section{Bronnen}

\section{Inleiding}

- L.O. Fresco (2012). Hamburgers in Paradijs. Voedsel in tijden van schaarste en overvloed. Bert Bakker uitgeverij, Amsterdam.

- Sara Menker (2017) The world could run out of food two decades earlier than thought. Africa Quartz, https://qz.com/1064653/the-world-could-run-out-of-food-two-decades-earlier-than-thought/

- Ministerie Economische Zaken (2016). Toekomstbestendige Agrofood export. Brief aan de Tweede Kamer DGAN-ELVV/1613987, 23 september 2016.

https://www.rijksoverheid.nl/documenten/kamerstukken/2016/09/24/kamerbrieftoekomstbestendige-agrofood-export

- Adviesraad Internationale Vraagstukken (2016). Daadkracht door de Dutch Diamond: ondernemen in het licht van de nieuwe duurzame ontwikkelingsdoelen. Advies 99. https://aivadvice.nl/8j2/publicaties/adviezen/daadkracht-door-de-dutch-diamond-ondernemen-in-het-lichtvan-de-nieuwe-duurzame-ontwikkelingsdoelen

\section{Beleidscontext}

- Ministerie Economische Zaken (2016). Toekomstbestendige Agrofood export. Brief aan de Tweede Kamer DGAN-ELVV/1613987, 23 september 2016.

https://www.rijksoverheid.nl/documenten/kamerstukken/2016/09/24/kamerbrieftoekomstbestendige-agrofood-export

- Anon. (2017). Regeerakkoord Vertrouwen in de toekomst. https://www.rijksoverheid.nl/regering/regeerakkoord-vertrouwen-in-de-toekomst

\section{Globale uitdagingen}

- Fang, S. (2015). Presentation IFPRI at Wageningen University

- Balzelj, B. et al (2014) importance of food-demand management for climate mitigation. Nature Climate Change 4, 924-929. https://www.nature.com/articles/nclimate2353

- Lipinski, B. (2013) Reducing food loss and waste. World resource Institute Working paper, June 2013. http://pdf.wri.org/reducing food loss and waste.pdf

- Trulab (n.y.) Urbanization on the rise. http://trulab.org/intro3/

\section{Oplossingen op drie niveaus}

- Van Berkum et al (2017). Dynamics of food systems in Sub Saharan Africa. Implications for consumption patterns and farmer's position in food supply chain. Wageningen, Wageningen Economic Research Report 2017-072. http://edepot.wur.nl/417176

\section{Actoren}

- Thijssen, C. (2017). Deze 7 agrifood-bedrijven scoren in de MKB-top 100. Duurzaambedrijfsleven.nl https://www.duurzaambedrijfsleven.nl/voeding/24935/deze-7-agrifood-bedrijven-scoren-in-de-mkbtop-100

- Anon (2016) Building highways to SDG investing. PGGM, Zeist. https://www.pggm.nl/wie-zijnwe/pers/Documents/Building-Highways-to-SDG-Investing.pdf

- Boschma, E. (2017) Global challenges, Dutch solutions. VNO-NCW, Den Haag. https://www.vnoncw.nl/system/files force/global challenges dutch solutions.pdf

- Natural Capital coalition (2016). "Natural Capital Protocol". www.naturalcapitalcoalition.org/protocol 


\section{Regio's}

- World Economic Forum (2017). African Competitiveness report. Gland. https://www.weforum.org/reports/africa-competitiveness-report-2017

- UNECA (2011). African Youth Report. United Nationas Ecnomic Commission for Africa. https://www.uneca.org/publications/serie/African-Youth-Report

- Ekekwe, N. (2017). How digitcal technology is changing farming in Africa. Harvard Business Review. https://hbr.org/2017/05/how-digital-technology-is-changing-farming-in-africa

7. Relevante investeringsopties

- Fresco, L.O. et al (2017). Food transitions 2030. Wageningen. www.wur.eu/mansholt 
Wageningen Environmental Research Postbus 47

6700 AA Wageningen

T 0317480700

www.wur.nl/environmental-research

Wageningen Environmental Research Rapport 2874

ISSN 1566-7197
De missie van Wageningen University \& Research is 'To explore the potential of nature to improve the quality of life'. Binnen Wageningen University \& Research bundelen Wageningen University en gespecialiseerde onderzoeksinstituten van Stichting Wageningen Research hun krachten om bij te dragen aan de oplossing van belangrijke vragen in het domein van gezonde voeding en leefomgeving. Met ongeveer 30 vestigingen, 5.000 medewerkers en 10.000 studenten behoort Wageningen University \& Research wereldwijd tot de aansprekende kennisinstellingen binnen haar domein. De integrale benadering van de vraagstukken en de samenwerking tussen verschillende disciplines vormen het hart van de unieke Wageningen aanpak. 



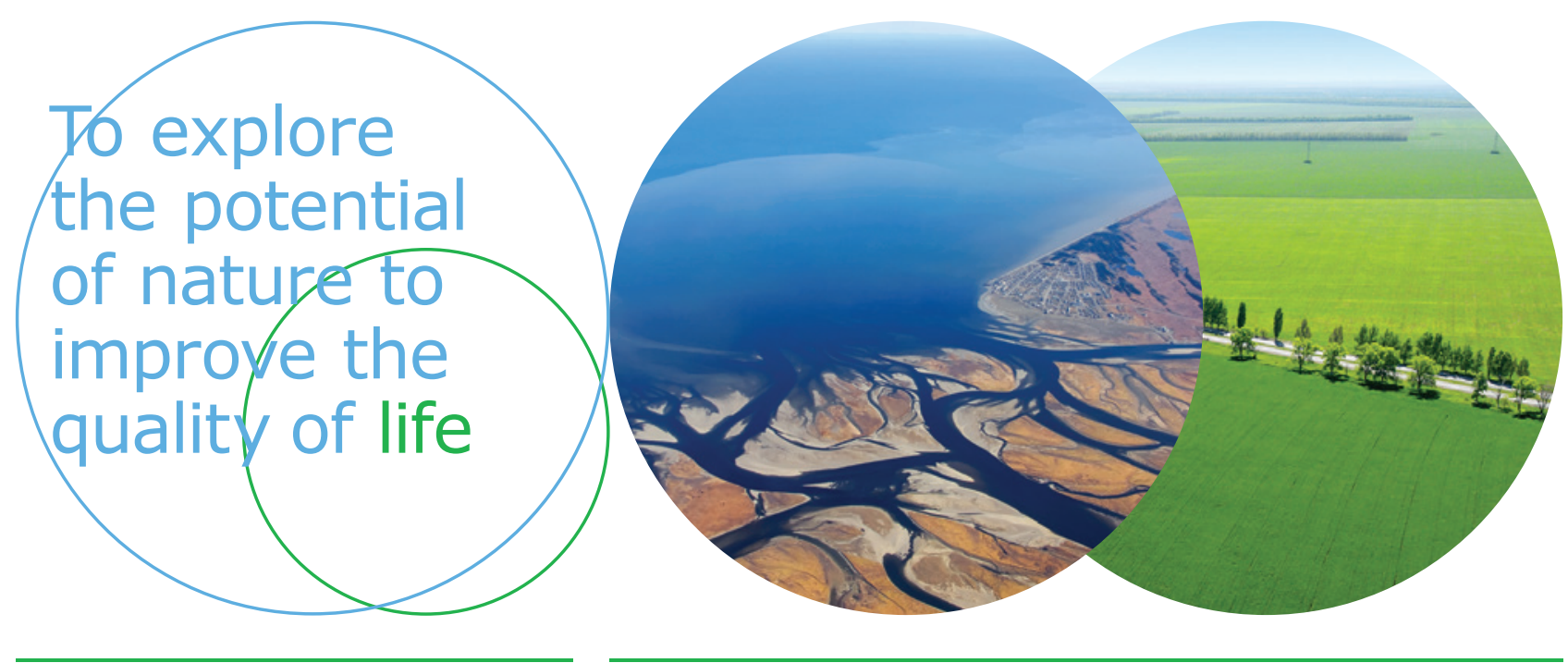

Wageningen Environmental Research Postbus 47

$6700 \mathrm{AB}$ Wageningen

T 317480700

www.wur.nl/environmental-research

Rapport 2874

ISSN 1566-7197
De missie van Wageningen University \& Research is 'To explore the potential of nature to improve the quality of life'. Binnen Wageningen University \& Research bundelen Wageningen University en gespecialiseerde onderzoeksinstituten van Stichting Wageningen Research hun krachten om bij te dragen aan de oplossing van belangrijke vragen in het domein van gezonde voeding en leefomgeving. Met ongeveer 30 vestigingen, 5.000 medewerkers en 10.000 studenten behoort Wageningen University \& Research wereldwijd tot de aansprekende kennisinstellingen binnen haar domein. De integrale benadering van de vraagstukken en de samenwerking tussen verschillende disciplines vormen het hart van de unieke Wageningen aanpak. 